\title{
Ectasia After Corneal Refractive Surgery: A Systematic Review
}

\author{
Majid Moshirfar (D) - Alyson N. Tukan · Nour Bundogji • \\ Harry Y. Liu - Shannon E. McCabe $\cdot$ Yasmyne C. Ronquillo • \\ Phillip C. Hoopes
}

Received: June 4, 2021 / Accepted: August 2, 2021 / Published online: August 20, 2021

(C) The Author(s) 2021

\section{ABSTRACT}

Introduction: The incidence of ectasia following refractive surgery is unclear. This review sought to determine the worldwide rates of ectasia after photorefractive keratectomy (PRK), laser-assisted in situ keratomileusis (LASIK), and small incision lenticule extraction (SMILE) based on reports in the literature.

Methods: A systematic review was conducted according to modified Preferred Reporting Items for Systematic Reviews and Meta-Analyses

M. Moshirfar ( $₫)$. S. E. McCabe · Y. C. Ronquillo · P. C. Hoopes

Hoopes Vision Research Center, Hoopes Vision, 11820 S. State Street Suite \#200, Draper, UT 84020, USA

e-mail: cornea2020@me.com

M. Moshirfar

John A. Moran Eye Center, University of Utah

School of Medicine, Salt Lake City, UT, USA

M. Moshirfar

Utah Lions Eye Bank, Murray, UT, USA

A. N. Tukan · N. Bundogji

University of Arizona College of Medicine-Phoenix, Phoenix, AZ, USA

H. Y. Liu

McGovern Medical School at The University of

Texas Health Science Center at Houston, Houston,

TX, USA

S. E. McCabe

Mission Hills Eye Center, Pleasant Hill, CA, USA
(PRISMA) guidelines. Publications were identified by a search of eight electronic databases for relevant terms between 1984 and 2021. Patient characteristics and preoperative values including manifest refractive spherical refractive equivalent (MRSE), central corneal thickness (CCT), anterior keratometry, postoperative residual stromal bed (RSB), and percent tissue altered (PTA) were summarized. In addition, annual rates of each refractive surgery were determined, and incidence of post-refractive ectasia for each type was calculated using the number of ectatic eyes identified in the literature.

Results: In total, 57 eyes (70 eyes including those with preoperative risk factors for ectasia) were identified to have post-PRK ectasia, while 1453 eyes (1681 eyes including risk factors) had post-LASIK ectasia, and 11 eyes (19 eyes including risk factors) had post-SMILE ectasia. Cases of refractive surgery performed annually were estimated as 283,920 for PRK, $1,608,880$ for LASIK, and 96,750 for SMILE. Reported postrefractive ectasia in eyes without preoperative identifiable risk factors occurred with the following incidences: 20 per 100,000 eyes in PRK, 90 per 100,000 eyes in LASIK, and 11 per 100,000 eyes in SMILE. The rate of ectasia in LASIK was found to be 4.5 times higher than that of PRK.

Conclusion: Post-refractive ectasia occurs at lower rates in eyes undergoing PRK than LASIK. Although SMILE appears to have the lowest rate 
of ectasia, the number of cases already reported since its recent approval suggests that postSMILE ectasia may become a concern. Considering that keratoconus is a spectrum of disease, pre-existing keratoconus may play a larger role in postoperative ectasia than previously accounted for in the literature.

Keywords: Ectasia; Ectasia risk score system; Incidence; Keratectasia; Keratoconus; LASIK; Prevalence; PRK; SMILE

\section{Key Summary Points}

Based on a literature review of all reported cases of ectasia, the incidence of postrefractive ectasia in eyes without identifiable preoperative risk factors is 20 per 100,00 eyes for PRK, 90 per 100,000 eyes for LASIK, and 11 per 100,000 eyes for SMILE

Ectasia was found to be 4.5 times more likely after LASIK than PRK

Although SMILE appears to have the lowest rate of ectasia, its incidence may increase as more procedures are performed and cases are reported

The prevalence of keratoconus in the general population may contribute to postoperative ectasia, as patients seeking refractive surgery could have subclinical disease

The present study poses the question whether iatrogenic post-refractive ectasia may be a progression of pre-existing keratoconus

\section{INTRODUCTION}

Corneal refractive surgery encompasses multiple modalities, including photorefractive keratectomy (PRK), laser-assisted in situ keratomileusis (LASIK), and small-incision lenticule extraction (SMILE). Since its approval by the Food and Drug Administration (FDA) in 1999, LASIK has emerged as the most prevalent of these surgical options because of the rapid improvement in visual outcomes with relatively few adverse effects $[1,2]$. However, LASIK carries a risk of ectasia, characterized by inferior corneal steepening, worsening myopic astigmatism, and loss of best corrected visual acuity [3]. The first cases of post-LASIK ectasia were documented by Theo Seiler in 1998 in three highly myopic patients with thin corneas [4]. With the high annual volume of LASIK cases, post-LASIK ectasia has become a well-known adverse event, though high variability of incidence recorded in the literature $(0.013 \%$ [5] to $0.935 \%$ [6]) limits preoperative risk counseling. Furthermore, the incidence of ectasia after PRK and SMILE is poorly understood. The present study sought to report the incidence of ectasia in three modalities of corneal refractive surgery (PRK, LASIK, and SMILE) based on currently reported cases worldwide. This incidence was stratified by presence of identifiable preoperative risk factors for ectasia. Patient characteristics are also summarized to identify trends in the development of post-refractive ectasia.

\section{METHODS}

\section{Literature Search}

A systematic review was conducted according to modified Preferred Reporting Items for Systematic Reviews and Meta-Analyses (PRISMA) guidelines [7]. The following criteria were not applied to this review: protocol registration; public reporting of data analysis; and assessment of risk of bias, certainty, confidence/credibility interval, heterogeneity, and sensitivity. The reviewers claim no conflicts of interest. The following electronic databases were searched, with last access on June 2, 2021: PubMed, Scopus, Ovid Medline, Embase, ScienceDirect, Google Scholar, Cochrane, and Clinicaltrials.gov. Key words used in the search queries included a combination of the following terms: "ectasia," "keratectasia," "keratoconus," "photorefractive keratectomy," "PRK," "laser 
epithelial keratomileusis," "LASEK," “epikeratome laser-assisted keratomileusis," "EpiLASIK," "laser-assisted in situ keratomileusis," "LASIK," "small incision lenticule extraction," "SMILE," "ReLEx SMILE," and "incidence." There were no language restrictions. Publications retrieved included any cases of postoperative ectasia reported worldwide since the introduction of each refractive surgery (1984-2021 for PRK, 1998-2021 for LASIK, and 2012-2021 for SMILE).

Two independent examiners reviewed resulting publications and excluded articles that met any of the following criteria: unrelated search results; duplicate publications; refractive procedures other than PRK, LASIK, SMILE, LASEK, and epi-LASIK; non-refractive ectasia, and studies that did not differentiate patients with primary keratoconus versus postoperative ectasia. Due to the multitude of publications on LASIK that may potentially report the same cases, the reviewers excluded subsequent publications from the same author in which a unique patient population was not clearly identified. Inconsistencies in identifying the number of patients in each population of ectatic eyes prevented the reviewers from reporting results as such. A visual representation of the literature review process is reflected in Fig. 1.

Included articles were categorized by the presence of preoperative identifiable risk factors for ectasia. Risk factors were defined as "keratoconus suspect," forme fruste keratoconus, and pellucid marginal degeneration. Eyes without identifiable risk factors were those with no preoperative abnormalities or preoperative topography with asymmetric bowtie, inferior steepening, and skewed radial axis. If preoperative topography was not mentioned, patients were assumed to be good surgical candidates and were thus grouped in the no risk factor subcategory. This review did not consider patient characteristics including age, manifest refractive spherical refractive equivalent (MRSE), central corneal thickness (CCT), and predicted residual stromal bed (RSB) among the identifiable preoperative risk factors. These patient characteristics have been validated for ectasia risk assessment in LASIK but not PRK and SMILE. Thus, these factors were not

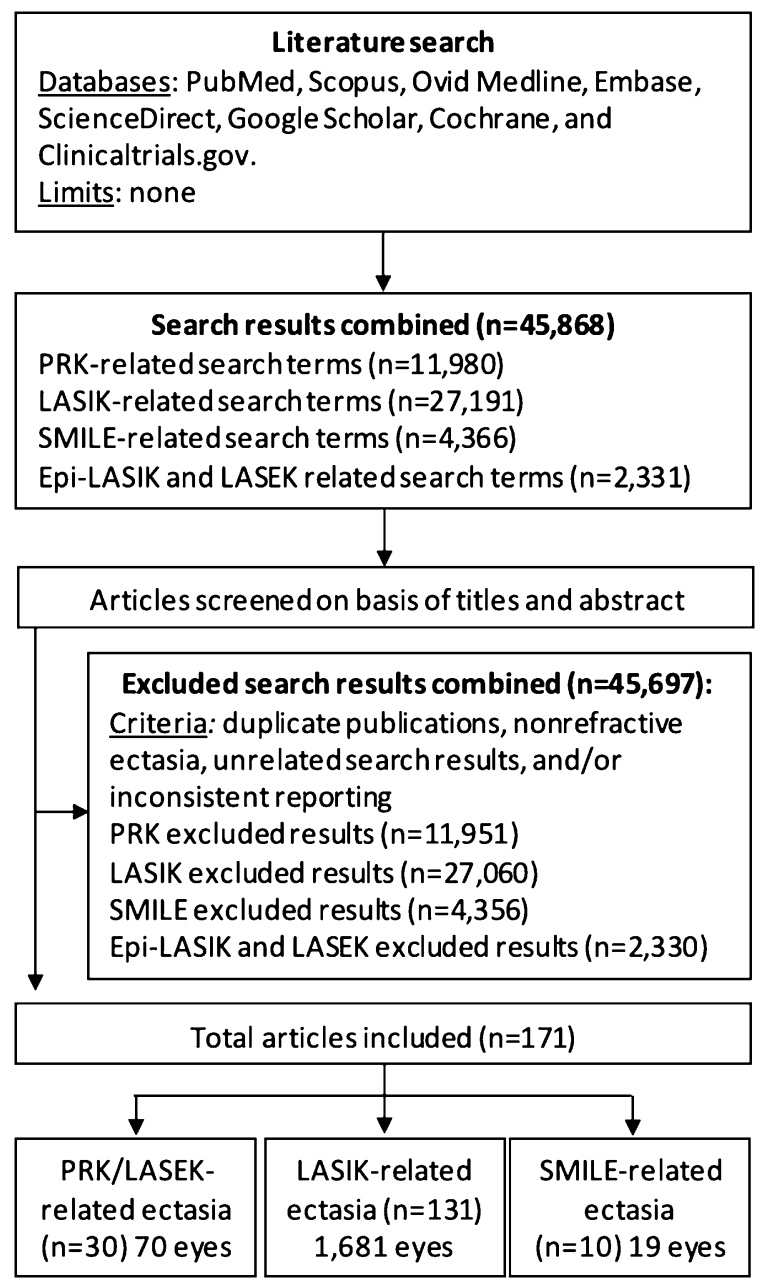

Fig. 1 Diagram of article selection adapted from PRISMA guidelines ( $n=$ number of articles)

considered for patient stratification to maintain consistency across the included corneal refractive surgeries.

\section{Rates of Refractive Surgery}

Exact yearly refractive surgical rates are not publicly available for PRK, LASIK, and SMILE. Thus, estimations were made by extrapolation from rates reported in the literature [8], as outlined in Figs. 2 and 3 and described below. Rates within the US and internationally were calculated separately to account for the introduction of SMILE, then were added together to yield a worldwide annual estimate of each refractive procedure. 


\section{Estimated Volume of Corneal Refractive Surgery in the US}

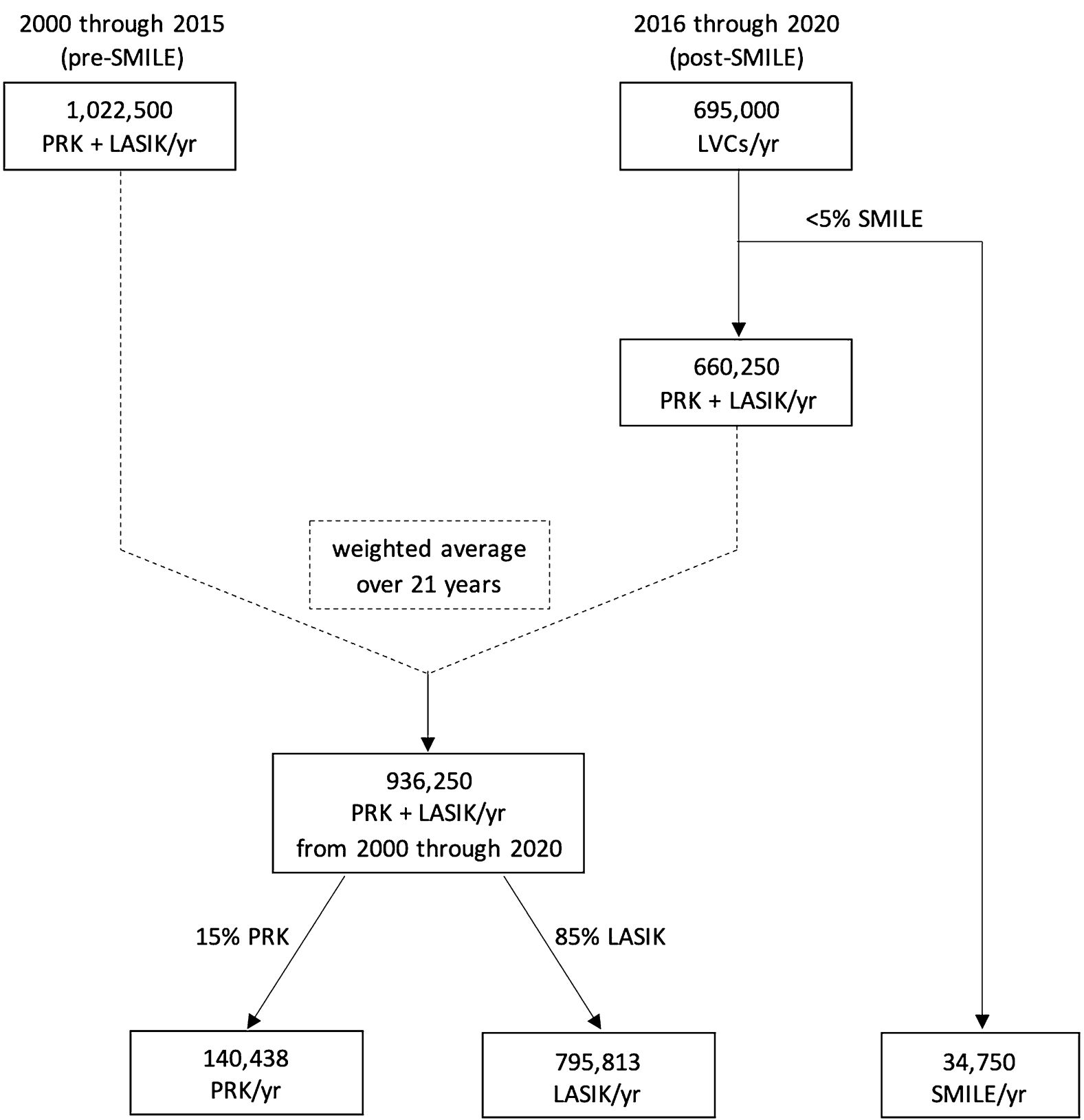

Fig. 2 Schematic displaying extrapolated annual surgical rates of PRK, LASIK, and SMILE in the US. Weighted average was calculated to account for changes in refractive

\section{United States}

The number of laser vision correction (LVC) procedures, which include LASIK, PRK, and SMILE, among others, is reported by Joffe as a surgery rates with the introduction of SMILE. Laser vision correction (LVC) represents PRK, LASIK, and SMILE procedures combined

yearly estimate from 1990 to 2020 [8]. Because of the varied prevalence of LVCs over time, the number of annual LVCs was averaged based on pre- and post-FDA approval of SMILE in 2016. 
Estimated Volume of Corneal Refractive Surgery Internationally

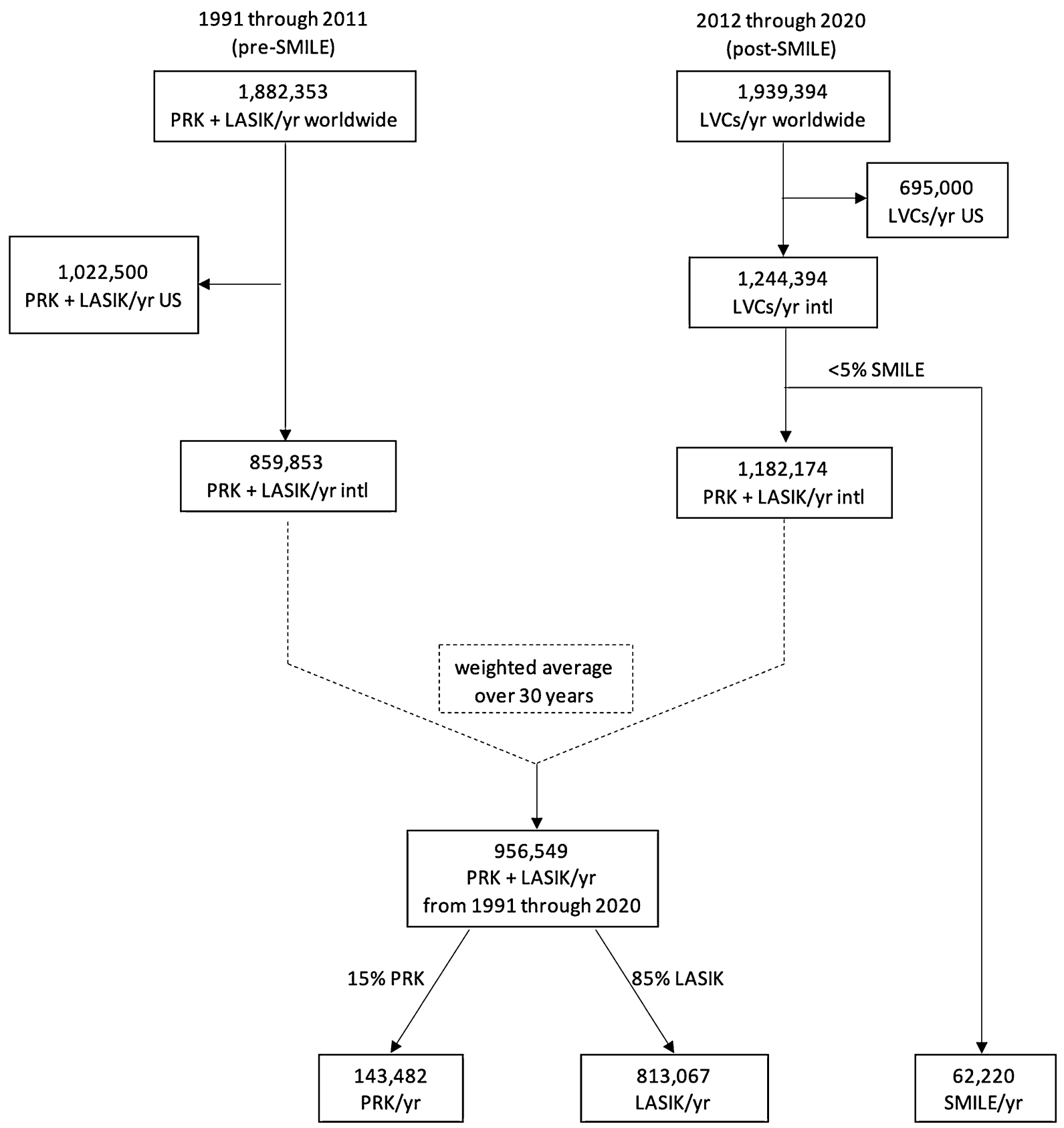

Fig. 3 Schematic displaying extrapolated annual surgical rates of PRK, LASIK, and SMILE internationally. Weighted average was calculated to account for changes

Using Joffe's estimate that SMILE comprises < $5 \%$ of LVCs, 34,750 cases of SMILE were deducted from the LVCs between 2016 and 2020. A weighted average was then calculated in refractive surgery rates with the introduction of SMILE. Laser vision correction (LVC) represents PRK, LASIK, and SMILE procedures combined

for PRK and LASIK between 2000 and 2020 (21 years). Since this annual rate included only LASIK and PRK cases, Joffe's estimate then was applied such that $15 \%$ of cases were calculated 
as PRK and $85 \%$ as LASIK to yield an annual rate of each procedure in the US (Fig. 2).

\section{International}

In the following description, "worldwide" refers to the number of cases globally including the US, while "international" refers to cases outside the US. From 1991 through 2015, it was reported that 40 million LASIK procedures were performed worldwide [2]. The average, as calculated over 25 years, was 1.6 million LASIK procedures performed annually worldwide. Joffe's estimate was applied such that the 1.6 million annual LASIK cases accounted for $85 \%$ of LVCs performed worldwide per year from 1991 to 2012. The annual rate of LVCs preSMILE in the US was subtracted from worldwide LVCs (PRK + LASIK) to yield total LVCs per year internationally. Post-SMILE, the rate of LASIK cases was assumed to be $82.5 \%$, the average of the $80-85 \%$ range set forth by Joffe to account for the introduction of SMILE. The number of LVCs per year in the US during the time period in which SMILE was in practice was subtracted to yield total LVCs (PRK + LASIK + SMILE) performed internationally between 2012 and 2020. The estimated 5\% of SMILE cases was subtracted for a total of PRK and LASIK cases per year internationally. The weighted average over 30 years was calculated between 1991 and 2020 (30 years), yielding an average number of PRK and LASIK cases per year internationally. Joffe's estimate was then applied such that $15 \%$ of cases were calculated as PRK and $85 \%$ as LASIK to yield an annual rate of each procedure internationally (Fig. 3).

\section{Worldwide}

The annual worldwide rates of PRK, LASIK, and SMILE were calculated by adding the annual US and international rates of each refractive procedure.

\section{Calculation of Incidence}

To determine the annual incidence of post-refractive ectasia worldwide, the total number of ectatic eyes identified in this literature review was divided by the yearly rate of each procedure, as calculated above (Table 1).

\section{Patient Characteristics}

Two independent reviewers collected patient characteristics when available, though not all reported results were compatible with the domains of characteristics being analyzed. Patient characteristics were reviewed for age, sex, MRSE, preoperative anterior keratometry, CCT, preoperative topography findings, calculated or reported percent tissue altered (PTA), RSB, and time to onset of ectasia. Studies that reported summary characteristics rather than individual patient data were included in calculations as a single value (represented as a mean) and range. Myopia was categorized using the following criteria: low: -0.5 to $<-3.0$ diopters (D); moderate: -3.0 to $<-6.0 \mathrm{D}$; high:

Table 1 Estimated incidence of reported ectasia in each cornea refractive surgery type

\begin{tabular}{llllll}
\hline $\begin{array}{l}\text { Refractive } \\
\text { surgery }\end{array}$ & $\begin{array}{l}\text { Avg total procedures } \\
\text { per year }\end{array}$ & $\begin{array}{l}\text { Ectatic eyes } \\
\text { w/o RF* }\end{array}$ & $\begin{array}{l}\text { Incidence of ectasia } \\
\text { w/o RF (\%) }\end{array}$ & $\begin{array}{l}\text { Total ectatic } \\
\text { eyes** }\end{array}$ & $\begin{array}{l}\text { Total incidence of } \\
\text { ectasia (\%) }\end{array}$ \\
\hline PRK & 283,920 & 57 & 0.020 & 70 & 0.025 \\
LASIK & $1,608,880$ & 1453 & 0.090 & 1681 & 0.100 \\
SMILE & 96,750 & 11 & 0.011 & 19 & 0.020 \\
\hline
\end{tabular}

PRK photorefractive keratectomy, LASIK laser-assisted in situ keratomileusis, SMILE small-incision lenticule extraction, $w / o$ without, $R F$ risk factors

${ }^{*}$ Ectatic eyes identified postoperatively without preexisting risk factors

${ }^{* *}$ Ectatic eyes identified with and without preexisting risk factors 
-6.0 to $<-9.0 \mathrm{D}$; or severe: $\geq-9.0 \mathrm{D}$. CCT was stratified by thickness based on the average CCT in normal eyes [9]: $<500 \mu \mathrm{m} ; 500-524 \mu \mathrm{m}$; $525-570 \mu \mathrm{m} ;>570 \mu \mathrm{m}$. PTA, when not reported, was calculated using the following equations: PTA $=($ ablation depth $+50 \mu \mathrm{m}) / \mathrm{CCT}$ for PRK; PTA $=($ flap thickness + ablation depth $) /$ CCT for LASIK; and PTA = (cap thickness + lenticule thickness)/CCT for SMILE. The risk factors assessed in the Ectasia Risk Score System (ERSS) [10] were reported for PRK, SMILE and $10 \%$ of LASIK cases due to inconsistencies in available data.

\section{Keratoconus Incidence}

To better understand the interplay between post-refractive ectasia and pre-existing keratoconus, a literature search was conducted using the aforementioned search engines. The following search terms were utilized: "incidence," "prevalence," and "keratoconus."

\section{Compliance with Ethics Guidelines}

This article is based on previously conducted studies and does not contain any new studies with human participants or animals performed by any of the authors.

\section{Statistical Analysis}

Statistical analyses were performed using RStudio (RStudio, Inc. Released 2018. RStudio for Macintosh, Version 1.1.456. Boston, MA, USA: RStudio Inc.). Patient characteristics were compared across surgery type using ANOVA with post-hoc Tukey HSD. A Fisher's exact test was used to determine if preoperative myopia level and stratified CCT varied significantly.

\section{RESULTS}

\section{Literature Review}

PRK-The literature review of post-PRK ectasia resulted in 11,980 articles, of which 11,951 were excluded, yielding 29 articles [11-39]. In total,
70 eyes were reported to have ectasia related to PRK. Of these eyes, 57 had post-PRK ectasia with no identifiable preoperative risk factors, including one eye from a LASEK case. Thirteen eyes had identifiable preoperative risk factors (Fig. 1). The literature review of post-LASEK and epi-LASIK ectasia yielded 2331 articles, of which 2330 were excluded. The one eye with postLASEK ectasia was grouped into PRK as mentioned above [40].

LASIK-Search results for post-LASIK ectasia resulted in 27,191 articles, of which 27,060 were excluded, yielding 131 articles $[1,3-6,10,23-25,32,33,41-160]$. In total, 1681 eyes were reported to have ectasia related to LASIK. Of these eyes, 1453 had no identifiable preoperative risk factors, while 228 eyes had identifiable preoperative risk factors (Fig. 1).

SMILE-Search results for post-SMILE ectasia resulted in 4366 articles, of which 4356 were excluded, yielding 10 articles [161-170]. In total, 19 eyes were reported to have ectasia related to SMILE. Of these eyes, 11 had no identifiable preoperative risk factors, while 8 eyes had identifiable preoperative risk factors (Fig. 1).

\section{Estimation of Refractive Surgery Rates}

In the US pre-SMILE (2000 through 2015), there were 1,022,500 estimated PRK and LASIK cases per year. Post-SMILE (2016 through 2020), there were 695,000 estimated LVCs (PRK + LASIK + SMILE), of which 34,750 SMILE procedures were subtracted for a total of 660,250 PRK and LASIK procedures per year in the US. A weighted average was calculated over 21 years, resulting in 936,250 PRK and LASIK procedures per year. Fifteen percent $(140,438$ procedures) were estimated to be PRK, and $85 \%$ (795,813 procedures) were estimated to be LASIK (Fig. 2).

Worldwide pre-SMILE (1991 through 2011), there were $1,882,350$ estimated PRK and LASIK cases per year. Post-SMILE (2012 through 2020), there were 1,939,394 estimated LVCs (PRK + LASIK + SMILE). US LVCs were subtracted preand post-SMILE, yielding 859,853 LVCs (PRK + LASIK) and 1,244,394 LVCs (PRK + 


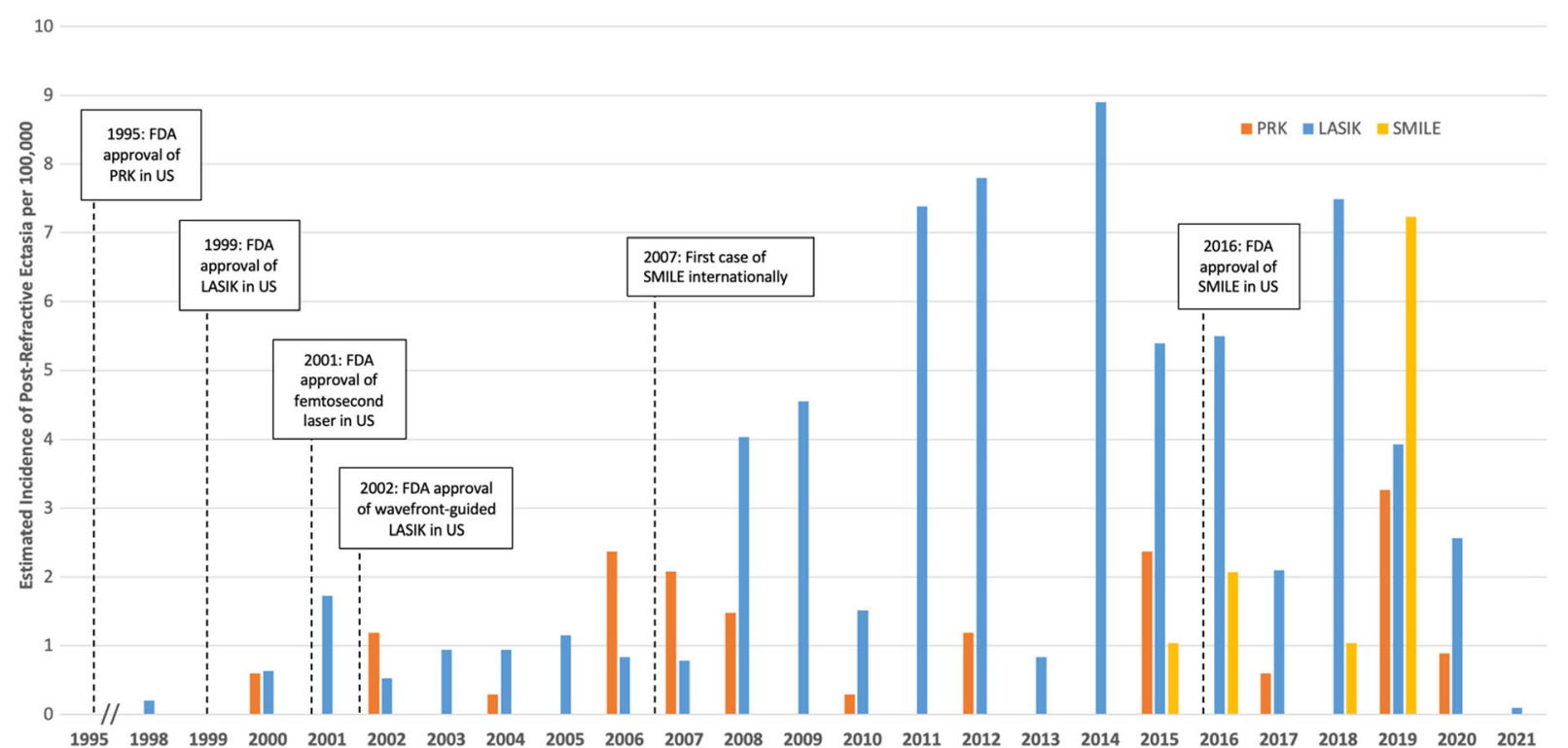

Fig. 4 Incidence of ectasia after PRK (orange), LASIK (blue), and SMILE (yellow) worldwide between 1998 and 2021 for cases without identifiable preoperative risk

LASIK + SMILE) internationally, respectively. Five percent $(62,220)$ of SMILE procedures were subtracted from post-SMILE LVCs, resulting in $1,182,174$ PRK and LASIK procedures per year internationally from 2012 through 2020. A weighted average was calculated over 30 years, resulting in 956,549 PRK and LASIK procedures internationally per year. Fifteen percent of 143,482 procedures were estimated to be PRK and $85 \%(813,067$ procedures) were estimated to be LASIK (Fig. 3).

The annual worldwide rate of each procedure was calculated as 283,920 for PRK, 1,608,880 for LASIK, and 96,750 for SMILE.

\section{Incidence}

Table 1 summarizes the number of eyes with post-refractive ectasia, including those with and without identifiable preoperative risk factors for PRK, LASIK, and SMILE. The calculated worldwide incidence is also reported. In eyes without risk factors, the incidence of post-refractive ectasia was $0.020 \%$ (20 eyes per 100,000), $0.090 \%$ (90 eyes per 100,000), and 0.011\% (11 eyes per 100,000) for PRK, LASIK, and SMILE, respectively. The total incidence, including eyes factors, in conjunction with relevant events in the history of corneal refractive surgery

with preoperative risk factors, was $0.025 \%$ (25 eyes per 100,000$), 0.100 \%$ (100 eyes per 100,000 ), and $0.020 \%$ (20 eyes per 100,000 ) for PRK, LASIK, and SMILE, respectively. The worldwide incidences over time are displayed in Fig. 4, along with FDA approval of each refractive procedure. Reported incidences of post-PRK and post-LASIK ectasia from large-scale case series are organized by year in Table 2 . Two of these articles reported preoperative forme fruste keratoconus, and an adjusted incidence without identifiable preoperative risk factors is reflected.

\section{Patient Characteristics}

Patient characteristics are summarized in Table 3. There was no significant difference in the mean age of patients who developed ectasia after each procedure (34 \pm 11 years PRK, $33 \pm 8$ years LASIK, $28 \pm 7$ years SMILE; $p=0.26$ ). The onset of ectasia ranged from 0.2 to 192 months across the three procedures with a mean of $41 \pm 50$ months in PRK, $35 \pm 24$ months in LASIK, and $18 \pm 13$ months in SMILE; $p=0.06$. Of cases that reported the method of LASIK flap creation, $46 \%$ (135 cases) utilized microkeratome and 54\% (161 cases) 
Table 2 Reported incidence of post-LASIK and post-PRK ectasia with and without identifiable preoperative risk factors

\begin{tabular}{|c|c|c|c|c|c|c|c|}
\hline Procedure & Study & Year & Country & $\begin{array}{l}\text { Reported rate of } \\
\text { ectasia }\end{array}$ & $\begin{array}{l}\text { Reported } \\
\text { incidence (\%) }\end{array}$ & $\begin{array}{l}\text { Rate of ectasia } \\
\text { w/o RF }\end{array}$ & $\begin{array}{l}\text { Incidence w/o } \\
\text { RF (\%) }\end{array}$ \\
\hline \multirow[t]{10}{*}{ LASIK } & $\begin{array}{l}\text { Pallikaris et al. } \\
\text { [1] }\end{array}$ & 2001 & Greece & $19 / 2873$ & 0.661 & - & - \\
\hline & $\begin{array}{r}\text { Randleman } \\
\text { et al. [3] }\end{array}$ & 2003 & US & $1 / 2500$ & 0.040 & $3 / 50,000$ & 0.006 \\
\hline & $\begin{array}{c}\text { Rad et al. } \\
{[146]}\end{array}$ & 2004 & Iran & $14 / 6941$ & 0.202 & - & - \\
\hline & $\begin{array}{l}\text { Reinstein } \\
\text { et al. [147] }\end{array}$ & 2006 & UK & $6 / 5212$ & 0.115 & - & - \\
\hline & $\begin{array}{l}\text { Condon et al. } \\
{[6]}\end{array}$ & 2007 & Ireland & $1 / 107$ & 0.935 & - & - \\
\hline & $\begin{array}{l}\text { Spadea et al. } \\
\text { [89] }\end{array}$ & 2012 & Italy & $23 / 4027$ & 0.571 & - & - \\
\hline & $\begin{array}{l}\text { Moshirfar } \\
\text { et al. [85] }\end{array}$ & 2014 & US & $5 / 1992$ & 0.251 & $1 / 1992$ & 0.050 \\
\hline & $\begin{array}{l}\text { Bohac et al. } \\
\text { [45] }\end{array}$ & 2018 & Croatia & $10 / 30,167$ & 0.033 & - & - \\
\hline & $\begin{array}{l}\text { Chua et al. } \\
{[52]}\end{array}$ & 2019 & Singapore & $12 / 53,731$ & 0.022 & - & - \\
\hline & $\begin{array}{r}\text { Schallhorn } \\
\text { et al. [5] }\end{array}$ & 2020 & UK & $8 / 61,833$ & 0.013 & - & - \\
\hline \multirow[t]{2}{*}{ PRK } & $\begin{array}{l}\text { Sorkin et al. } \\
{[13]}\end{array}$ & 2019 & Israel & $9 / 3105$ & 0.290 & - & - \\
\hline & $\begin{array}{r}\text { Schallhorn } \\
\text { et al. [5] }\end{array}$ & 2020 & UK & $1 / 9467$ & 0.011 & - & - \\
\hline
\end{tabular}

$R F$ risk factor, $P R K$ photorefractive keratectomy, LASIK laser-assisted in situ keratomileusis, SMILE small-incision lenticule extraction

utilized femtosecond laser. Stratified CCT showed significantly thinner corneas pre-PRK ectasia $(495 \pm 39 \mu \mathrm{m})$ compared to LASIK $(529 \pm 37 \mu \mathrm{m})(p<0.01)$. RSB was significantly higher in eyes that developed ectasia after PRK $(384 \pm 41 \mu \mathrm{m})$ than LASIK $(238 \pm 55 \mu \mathrm{m})$ and SMILE $(349 \pm 40 \mu \mathrm{m}) \quad(p<0.01)$. Reported or calculated PTA was significantly lower in PRK $(24 \pm 6 \%)$ compared to LASIK $(45 \pm 10 \%)$ $(p<0.01)$. Proportion of eyes in each procedure is stratified by severity of myopia in Fig. 5 , with significantly higher rates of postoperative ectasia occurring in patients with moderate preoperative myopia $(p=0.002)$. Stratified CCT showed that thinner corneas tended to undergo PRK (49\%), although not statistically significant ( $p=0.09$; Fig. 6). ERSS showed a higher concentration of cases in the low-risk point range (Table 4).

\section{Keratoconus}

The literature-reported incidence and prevalence of keratoconus were stratified into 
Table 3 Patient characteristics

\begin{tabular}{|c|c|c|c|c|}
\hline Parameter & PRK & LASIK & SMILE & $p$ value \\
\hline \multicolumn{5}{|l|}{ Eyes, $n(\%)$} \\
\hline $\mathrm{R}$ & $17(46)$ & $177(49)$ & $7(64)$ & \\
\hline $\mathrm{L}$ & $20(54)$ & $183(51)$ & $4(36)$ & \\
\hline Age $^{*}$ (years) & $34 \pm 11(18$ to 57$)$ & $33 \pm 8(18$ to 62$)$ & $28 \pm 7(23$ to 43$)$ & 0.26 \\
\hline \multicolumn{5}{|l|}{ Sex, $n(\%)$} \\
\hline $\mathrm{M}$ & $22(71)$ & $334(51)$ & $5(71)$ & \\
\hline $\mathrm{F}$ & $9(29)$ & $316(49)$ & $2(29)$ & \\
\hline Preoperative $\mathrm{MRSE}^{*}{ }^{\mathrm{a}}$ & $\begin{array}{l}-4.2 \pm 3.8(-12.8 \text { to } \\
7.6)\end{array}$ & $\begin{array}{l}-6.9 \pm 5.6(-28.0 \text { to } \\
18.5)\end{array}$ & $\begin{array}{l}-5.0 \pm 2.7(-8.8 \text { to } \\
-2.0)\end{array}$ & 0.33 \\
\hline $\begin{array}{l}\text { Preoperative anterior } \mathrm{Km}^{*} \\
\text { (D) }\end{array}$ & $\begin{array}{l}43.7 \pm 1.6(39.7 \text { to } \\
46.1)\end{array}$ & $43.6 \pm 1.8(39.4$ to 49.9$)$ & $43.6 \pm 1.7(40.9$ to 45.3$)$ & 0.97 \\
\hline Preoperative & $495 \pm 39(363$ to 555$)$ & $529 \pm 37(414$ to 631$)$ & $508 \pm 47(418$ to 582$)$ & $<0.01^{*}$ \\
\hline \multicolumn{5}{|l|}{$\mathrm{CCT}^{* a}(\mu \mathrm{m})$} \\
\hline $\begin{array}{l}\text { Ectasia } \\
\text { onset }^{*} \text { a (months) }\end{array}$ & \multicolumn{3}{|c|}{ onset $^{*}$ a (months) } & 0.06 \\
\hline Postoperative $\mathrm{RSB}^{* \mathrm{a}}(\mu \mathrm{m})$ & $384 \pm 41(285$ to 433$)$ & $238 \pm 55(80$ to 426$)$ & $349 \pm 40(305$ to 389$)$ & $<0.01^{* \dagger}$ \\
\hline $\operatorname{PTA}^{* a}(\%)$ & $24 \pm 6(15$ to 40$)$ & $45 \pm 10(23$ to 66$)$ & $37 \pm 4(32$ to 41$)$ & $<0.01^{\ddagger \#}$ \\
\hline
\end{tabular}

PRK photorefractive keratometry, LASIK laser-assisted in situ keratomileusis, SMILE small-incision lenticule extraction, MRSE manifest refractive spherical equivalent, $D$ diopters, $C C T$ central corneal thickness, $R S B$ residual stromal bed, $P T A$ percent tissue altered

${ }^{*}$ Reported as mean $\pm \mathrm{SD}$ (range)

* Significance between PRK and LASIK

$\dagger$ Significance between PRK and SMILE

\# Significance between LASIK and SMILE

a Tukey HSD

worldwide, high risk, and average risk subcategories. Within each category, the articles were reported according to year. Increasing incidence and prevalence were observed over time (Table 5).

\section{DISCUSSION}

This systematic review estimated the incidence of post-refractive ectasia in PRK, LASIK, and SMILE. For clarification of reporting, "incidence" in its original statistical definition means the number of new cases of a disease per unit time, often over 1 year [171]. However, the term incidence is used loosely in the literature to represent the occurrence of disease or the new cases observed within the time period of the investigation. The data collected in the present study also report disease occurrence rather than true incidence, though "incidence" is utilized for consistency with the literature.

In the present study, there was no difference between the frequency of ectasia in male and female patients, even though keratoconus as a whole tends to be more common in men [172]. Of the 296 LASIK cases with a documented method of flap creation, ectasia occurred more 


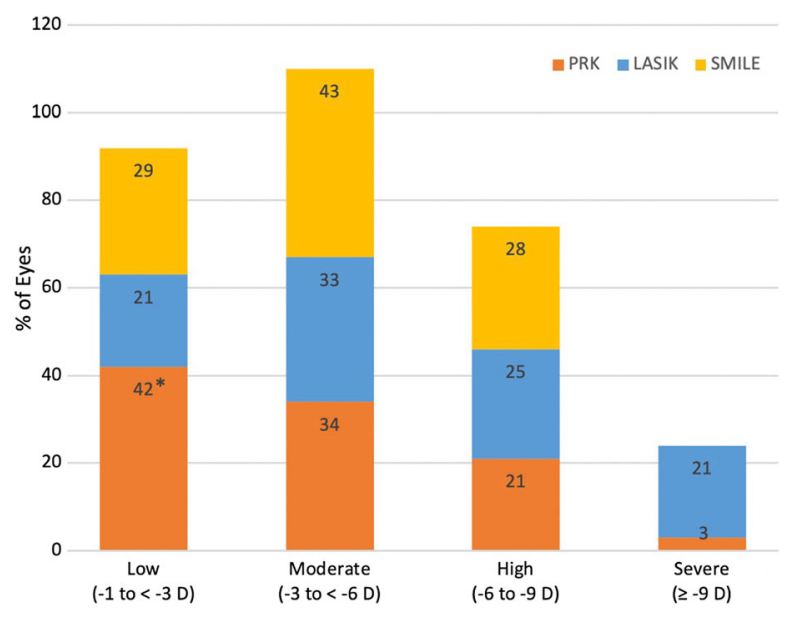

Fig. 5 Distribution of preoperative myopia in ectatic eyes without identifiable risk factors for ectasia that underwent PRK (orange), LASIK (blue), or SMILE (yellow) $(p=0.002)$. Proportion of eyes in each level of myopia adds to $100 \%$ across each type of corneal refractive surgery. *There was a significantly greater proportion of eyes in PRK with low myopia preoperatively compared to other myopia levels

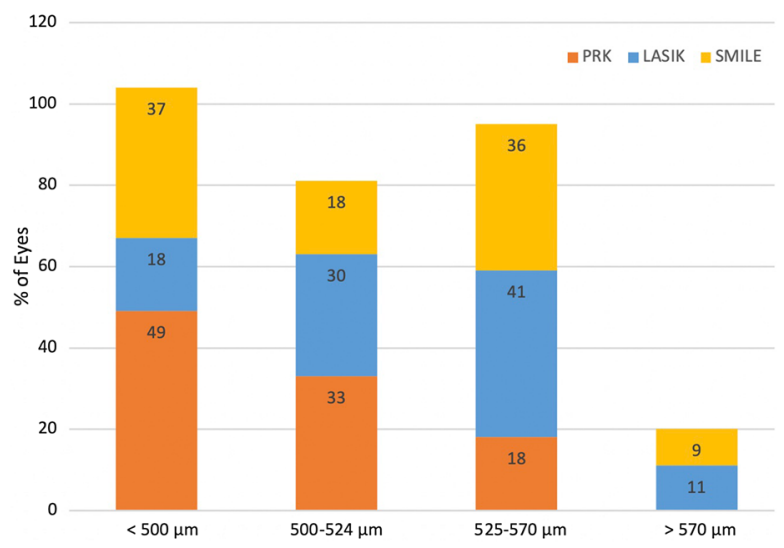

Fig. 6 Distribution of preoperative central corneal thickness (CCT) in ectatic eyes without identifiable risk factors for ectasia that underwent PRK (orange), LASIK (blue), or SMILE (yellow) $(p=0.09)$. Proportion of eyes in each category of CCT adds to $100 \%$ across each type of corneal refractive surgery

frequently with femtosecond laser (54\%) compared to microkeratome ( $46 \%)$, which may be due to the larger proportion of cases in this literature search occurring after introduction of the femtosecond laser. We would have expected lower rates of ectasia with femtosecond flap creation since this method is considered to make thinner and more predictable flaps [173]. Regarding post-PRK ectasia, the higher RSB and lower PTA compared to LASIK and SMILE are likely a reflection of the larger proportion of low myopes undergoing PRK. Ectatic eyes tended to have thinner corneas preoperatively in PRK than LASIK, aligning with the use of PRK for patients with thin corneas who are not candidates for LASIK. When assessing risk factors, ERSS is a validated tool for predicting postLASIK ectasia [10]. Interestingly, the ERSS calculated in the present study for patients who underwent PRK and SMILE showed that many eyes were considered low risk. Newer technologies, like the Corvis ST (Oculus Optikgeräte $\mathrm{GmbH}$, Wetzlar, Germany), attempt to fill this void in predicting preoperative risk by incorporating biomechanical studies into traditional Pentacam topography $[174,175]$. However, the data output by the Corvis ST is still not well understood, and further studies are needed to establish normal parameters before it can be a useful tool in evaluating preoperative risk.

The literature search in the present study confirms that cases of post-PRK ectasia are rare, with only 57 cases reported worldwide since 2000. Incidence of post-PRK ectasia from large case series is lacking, as only two such studies were identified $[5,13]$. These reported incidences were $0.011-0.029 \%$, comparable to the estimated incidence of worldwide post-PRK ectasia in the present study $(0.020 \%)$ in patients with no identifiable preoperative risk factors. LASIK has the most reports of post-refractive ectasia, for an estimated 1453 procedures and a worldwide incidence of $0.090 \%$. Reports of postLASIK ectasia in the literature range from $0.013 \%$ [5] up to $0.935 \%$ [6], for an average of $0.284 \%$. Although this study's estimated incidence falls within the range reported in the literature, it likely underestimates post-LASIK ectasia, and the large case studies in Table 4 that utilize discrete populations may be more representative of the true incidence. Post-LASIK ectasia may be more likely due to differences in postprocedural corneal tensile strength. It is estimated that the stroma only regains $2.4-28.1 \%$ of its original strength after LASIK in the central region and flap margin, respectively 
Table 4 Distribution of eyes according to ERSS scores for each risk parameter based on refractive surgery type

\begin{tabular}{|c|c|c|c|c|c|c|}
\hline & \multirow[t]{2}{*}{ Parameter } & \multicolumn{5}{|l|}{ Points } \\
\hline & & 4 & 3 & 2 & 1 & 0 \\
\hline \multirow[t]{5}{*}{ PRK } & Age & - & $13.9 \%$ & $25.0 \%$ & - & $61.1 \%$ \\
\hline & Topography & $5.9 \%$ & $38.2 \%$ & - & $14.7 \%$ & $41.2 \%$ \\
\hline & MRSE & - & $3.0 \%$ & - & $15.2 \%$ & $81.8 \%$ \\
\hline & Pachymetry & $6.3 \%$ & $12.5 \%$ & $50.0 \%$ & - & $31.3 \%$ \\
\hline & RSB & - & - & - & $9.1 \%$ & $90.9 \%$ \\
\hline \multirow{5}{*}{ LASIK } & Age & - & $5.2 \%$ & $8.6 \%$ & $18.3 \%$ & $52.4 \%$ \\
\hline & Topography & - & $9.5 \%$ & - & $13.8 \%$ & $46.6 \%$ \\
\hline & MRSE & $8.4 \%$ & $6.2 \%$ & $5.8 \%$ & $9.3 \%$ & $56.9 \%$ \\
\hline & Pachymetry & $2.3 \%$ & $5.2 \%$ & $20.7 \%$ & - & $56.3 \%$ \\
\hline & RSB & $16.6 \%$ & $16.0 \%$ & $10.9 \%$ & $11.4 \%$ & $26.3 \%$ \\
\hline \multirow[t]{5}{*}{ SMILE } & Age & - & - & $45.5 \%$ & $27.3 \%$ & $27.3 \%$ \\
\hline & Topography & $11.1 \%$ & - & - & $11.1 \%$ & $77.8 \%$ \\
\hline & MRSE & - & - & - & $28.6 \%$ & $71.4 \%$ \\
\hline & Pachymetry & - & - & - & - & $100.0 \%$ \\
\hline & RSB & - & - & - & $28.6 \%$ & $71.4 \%$ \\
\hline
\end{tabular}

A “ $-"$ indicates $0 \%$ reported for a given parameter

PRK photorefractive keratometry, LASIK laser-assisted in situ keratomileusis, SMILE small-incision lenticule extraction, ERSS ectasia risk score system, RSB residual stromal bed, MRSE manifest refractive spherical equivalent

[176]. This supports that the creation of a LASIK flap permanently disrupts the corneal integrity, predisposing patients to the onset or progression of ectasia.

Our calculations estimate that post-LASIK ectasia is approximately 4.5 times more likely than post-PRK ectasia in patients without identifiable preoperative risk factors. If we assume PRK volume accounts for $25 \%$ rather than $15 \%$ of LVCs in some parts of the world (536,182 PRK procedures worldwide), then the incidence of post-LASIK ectasia in patients without identifiable preoperative risk factors would be approximately eight times more likely than post-PRK ectasia. This suggests that the incidence of post-PRK ectasia may be more or less prevalent based on the frequency of procedures.
SMILE is a newer refractive surgery option; the pilot case was performed in 2007, and widespread implementation occurred between 2012 and 2016 [177]. SMILE is believed to preserve corneal integrity because the lenticule is extracted through a small corneal incision, leaving the anterior stroma unaffected [178]. Based on a mathematical model created by Reinstein et al., SMILE has a higher postoperative relative tensile strength than PRK and LASIK [178]. In the present study, 19 total cases, including 11 cases without identifiable preoperative risk factors, have already been reported over the 8 years that SMILE has been in practice, with more cases likely undocumented to date. Although LASIK had an estimated incidence of ectasia approximately eight times greater than SMILE, the relative infancy of SMILE as a refractive procedure impedes validation of the 
Table 5 Literature reported incidence and prevalence of keratoconus stratified into worldwide, average risk, and high-risk subcategories

\begin{tabular}{|c|c|c|c|c|}
\hline Study & Time period & Country & Incidence per 100,000 & Prevalence per 100,000 \\
\hline Rabinowitz [184] & 1998 & Worldwide & - & 50 \\
\hline Ferdi et al. [185] & 2019 & Worldwide & - & 86 \\
\hline Kennedy et al. [188] & $1935-1982$ & US & 2 & 54.5 \\
\hline Ihalainen [189] & $1964-1984$ & Finland & 1.5 & 30 \\
\hline Pearson et al. [180] & $1989-1999$ & UK & 4.5 & - \\
\hline Georgiou et al. [181] & $1994-2000$ & England & 3.3 & - \\
\hline Cozma et al. [182] & $1997-2001$ & $\mathrm{UK}$ & 3.5 & - \\
\hline Gorskova, Serosti'anov [190] & 1998 & Russia & - & 0.3 \\
\hline Bak-Nielsen et al. [183] & 2003 & Denmark & 1.2 & 44 \\
\hline Grünauer-Kloevekorn, Duncker [191] & 2006 & Germany & - & 50 \\
\hline Bak-Nielsen et al. [183] & 2011 & Denmark & 3.8 & - \\
\hline Godefrooij et al. [192] & 2011-2014 & Netherlands & 13 & - \\
\hline Pearson et al. [180] & 1989-1999 & UK & $20^{*}$ & - \\
\hline Georgiou et al. [181] & $1994-2000$ & England & $25^{*}$ & 270 \\
\hline Cozma et al. [182] & $1997-2001$ & UK & $32^{*}$ & - \\
\hline Assiri et al. [193] & $2001-2002$ & Saudi Arabia & 20 & - \\
\hline Ota et al. [172] & 2002 & Japan & $12 \mathrm{M} \mid 5 \mathrm{~F}$ & 50 \\
\hline Jonas et al. [194] & 2009 & India & - & 2300 \\
\hline Hwang et al. [195] & 2009-2014 & South Korea & 5.6 & 37 \\
\hline Millodot et al. [196] & 2011 & Israel & - & 2340 \\
\hline Ziaei et al. [197] & 2012 & Iran & 22.3 & - \\
\hline Althomali et al. [198] & 2018 & Saudi Arabia & - & 8590 \\
\hline Akowuah et al. [199] & 2021 & Africa & & 790 \\
\hline
\end{tabular}

${ }^{*}$ Asian subset

claim that SMILE achieves equivalent visual outcomes without the risk of postoperative ectasia. Considering that SMILE accounts for a substantially smaller proportion of refractive surgeries than LASIK, it appears that the trajectory of post-SMILE ectasia is concerning and difficult to predict at this time. It may only be a matter of time until additional cases of postSMILE ectasia are published.
The incidences reported in the present study reflect iatrogenic ectasia to the best of our knowledge, though not all authors report whether patients had abnormal preoperative topography. Furthermore, terms such as "suspicious topography" and "keratoconus suspect" are used loosely, and not all studies utilized the ERSS definition of "abnormal" [10]. Regardless, this study questions whether ectasia can truly 
be classified as iatrogenic rather than a progression of pre-existing subclinical keratoconus. To illustrate this point, one study reports a patient who developed bilateral ectasia after unilateral LASIK [145]. The patient had no evidence of abnormal topography or family history of ocular disease and thus was considered a good candidate for LASIK. Since he developed bilateral ectatic disease 20 months later, it seems likely the patient was predisposed to keratoconus, which emerged as a natural progression of the disease rather than a consequence of his unilateral refractive surgery. We propose that referring to post-refractive ectasia as "iatrogenic" inaccurately reflects the complexity of this disease and the multitude of preoperative factors that may be unidentified on initial surgical evaluation.

To better understand the interplay of keratoconus and post-refractive ectasia, we investigated the incidence and prevalence of keratoconus in the general population (Table 5). Reports of keratoconus in the literature fall short of representing the worldwide rates of keratoconus. Studies from Northern Europe are more readily available than other parts of the world, such as South America, where no reports were able to be obtained. However, keratoconus is a known problem in South America, as evidenced by the Violet June campaign started in Rio de Janeiro in 2018 to decrease eye rubbing [179]. Studies that stratify by ethnic groups and geographic regions demonstrate a wide range of calculated incidences. One example is in the UK, where the reported incidence of keratoconus for Asian patients was approximately four to nine times higher than for white patients from the same region [180-182]. When compared across similar studies, the incidence and prevalence of keratoconus seem to be increasing over time. For example, an incidence of 1.2 per 100,000 in 2003 and 3.8 per 100,000 in 2011 was reported in Denmark [183]; similarly, the Asian populations increased from 20 to 32 cases per 100,000 between 1989 and 2001 [180-182]. Worldwide prevalence increased from 50 per 100,000 in 1998 [184] to 86 per 100,000 in 2019 [185]. These studies likely under-report rates of keratoconus in the general population, as they do not capture all of the cases being treated in the private sector. However, it is important to note that increasing access to more sensitive technology may have uncovered previously undiagnosed cases. Considering that keratoconus is a spectrum of disease, it is possible that patients with keratoconus compose a larger percentage of post-refractive ectasia than what is currently documented.

There are several limitations to the present review. First, the estimated incidences in this study are limited by an absence of data reporting annual refractive procedures. Extrapolation was performed to approximate the number of cases of PRK, LASIK, and SMILE worldwide based on the ratios proposed by Joffe for US data [8]. However, Zeiss reports that over 3 million cases of SMILE were performed in 70 countries by 2020 [186], suggesting a higher prevalence of SMILE than the $5 \%$ accounted by the present study. Until a more transparent process of reporting refractive surgeries is developed, a truly representative number of annual cases is not achievable.

It is also imperative to have a more streamlined mechanism of reporting ectasia in order to understand the absolute incidence. In 2008, the European Registry of Quality Outcomes for Cataract and Refractive Surgery (EUREQUO) database was formed as a web-based system of reporting, though only 27,339 procedures have been documented over 10 years by 47 centers/surgeons [187]. Similarly, the International Society of Refractive Surgery (ISRS) ectasia registry has limited data access and transparency, making it difficult for the scientific community to readily understand rates of ectasia.

Underestimation of surgical volume and underreporting of ectatic eyes may have misrepresented the incidence of post-refractive ectasia. Furthermore, manual identification of eligible publications may have missed reports of post-refractive ectasia. Additionally, true incidence cannot be calculated as many articles do not indicate the time period over which their patients were included. Utilizing a weighted average as a step in the calculation of total procedures does not account for confounding factors causing annual fluctuation in the number of surgeries being performed, including financial insecurity, economic and population 
growth, disease outbreaks/pandemics, political climate, and technological advances. A more dynamic approach that could capture a realtime annual refractive procedure rate would provide more representative calculations. Additionally, this study identifies a need for streamlined documentation of patient characteristics such that robust evaluations of potential preoperative ectasia risk factors can be conducted.

\section{CONCLUSION}

In summary, conclusions about absolute incidence of post-refractive ectasia are elusive in the present climate of inconsistent reporting of both ectasia and cases of laser vision correction. We found that post-refractive ectasia occurs at low rates in eyes undergoing PRK, with an estimated incidence of 20 per 100,000 eyes $(0.020 \%)$. The preservation of corneal integrity with PRK is thought to be the reason for the low incidence, despite the observation that eyes with thinner corneas underwent PRK. The rate of ectasia in LASIK is 4.5 times higher than that of PRK, with an incidence of 90 per 100,000 eyes $(0.090 \%)$. SMILE has the lowest rate of ectasia in the present study with an incidence of 11 per 100,000 eyes $(0.011 \%)$, though the relative novelty of this procedure precludes confirmation that SMILE is superior to LASIK and PRK in this regard. The discussion of iatrogenic postrefractive ectasia is complicated by baseline rates of keratoconus in the general population, which are likely even higher than what has historically been reported. Considering that keratoconus is a spectrum of disease, it is possible that some patients diagnosed with iatrogenic ectasia actually had progression of preexisting subclinical keratoconus. In fact, there may be a selection bias in which patients seeking refractive surgery have a higher incidence of preoperative keratoconus because they are unhappy with their vision in contact lenses and glasses. The present study concludes that preexisting keratoconus may play a larger role in postoperative ectasia than what has been accounted for in the literature. Iatrogenic ectasia may in fact be a more complex phenomenon related to previously subclinical or mild keratoconus in the postoperative setting.

\section{ACKNOWLEDGEMENTS}

Special thanks to: Anisha N. Somani, James Barnes, Uma Vaidyanathan, Grant Hopping, Ayesha Patil, MacGregor Hall, Alex Villarreal, Preston Baker

Funding. This study was funded by an unrestricted grant from Research to Prevent Blindness (RPB), 360 Lexington Avenue, 22nd Floor New York, NY, 10017. No support was received for the publication of this article.

Authorship. All named authors meet the International Committee of Medical Journal Editors (ICMJE) criteria for authorship for this manuscript, take responsibility for the integrity of the work, and have given final approval to the version to be published.

Author contributions. Majid Moshirfar MD contributed to the study conception and design. Literature review, data collection and analysis were performed by Alyson Tukan, Nour Bundogji, and Harry Liu. The draft of the manuscript was written by Alyson Tukan, Nour Bundogji, and Harry Liu, and all authors contributed to revisions. All authors read and approved the final manuscript.

Disclosures. Majid Moshirfar MD, Alyson N. Tukan, Nour Bundogji, Harry Y. Liu, Shannon E. McCabe MD, Yasmyne C. Ronquillo MD, Phillip C. Hoopes MD have nothing to disclose.

Compliance with ethics guidelines. This article is based on previously conducted studies and does not contain any studies with human participants or animals performed by any of the authors.

Data availability. All data analyzed during this study are included in this published article as citations in the results section. 
Open Access. This article is licensed under a Creative Commons Attribution-NonCommercial 4.0 International License, which permits any non-commercial use, sharing, adaptation, distribution and reproduction in any medium or format, as long as you give appropriate credit to the original author(s) and the source, provide a link to the Creative Commons licence, and indicate if changes were made. The images or other third party material in this article are included in the article's Creative Commons licence, unless indicated otherwise in a credit line to the material. If material is not included in the article's Creative Commons licence and your intended use is not permitted by statutory regulation or exceeds the permitted use, you will need to obtain permission directly from the copyright holder. To view a copy of this licence, visit http://creativecommons.org/licenses/by$\mathrm{nc} / 4.0 /$.

\section{REFERENCES}

1. Pallikaris IG, Kymionis GD, Astyrakakis NI. Corneal ectasia induced by laser in situ keratomileusis. J Cataract Refract Surg. 2001;27(11):1796-802.

2. Stuart A. A look at LASIK past, present, and future. EyeNet Magazine. 2009. https://www.aao.org/ eyenet/article/look-at-lasikpast-present-future.

3. Randleman JB, Russell B, Ward MA, Thompson KP, Stulting RD. Risk factors and prognosis for corneal ectasia after LASIK. Ophthalmology. 2003;110(2): 267-75.

4. Seiler T, Koufala K, Richter G. Iatrogenic keratectasia after laser in situ keratomileusis. J Refract Surg. 1998;14(3):312-7.

5. Schallhorn JM, Schallhorn SC, Teenan D, Hannan SJ, Pelouskova M, Venter JA. Incidence of intraoperative and early postoperative adverse events in a large cohort of consecutive laser vision correction treatments. Am J Ophthalmol. 2020;1(210):97-106.

6. Condon PI, O'Keefe M, Binder PS. Long-term results of laser in situ keratomileusis for high myopia: Risk for ectasia. J Cataract Refract Surg [Internet]. 2007;33(4):583-90.

7. Liberati A, Altman DG, Tetzlaff J, Mulrow C, Gøtzsche PC, Ioannidis JPA, et al. The PRISMA statement for reporting systematic reviews and meta-analyses of studies that evaluate healthcare interventions: explanation and elaboration. BMJ. 2009;339:b2700.

8. Joffe SN. The 25th Anniversary of Laser Vision Correction in the United States. Clin Ophthalmol. 2021;15:1163-72.

9. Tananuvat N, Khumchoo N. Corneal thickness and endothelial morphology in Normal Thai eyes. BMC Ophthalmol. 2020;20(1):167.

10. Randleman JB, Trattler WB, Stulting RD. Validation of the ectasia risk score system for preoperative laser in situ keratomileusis screening. Am J Ophthalmol [Internet]. 2008;145(5):813-818.e2.

11. Barbara R, Zadok D, Pikkel J, et al. Collagen corneal cross-linking followed by intac implantation in a case of Post-PRK Ectasia. Int J Keratoconus Ectatic Corneal Dis. 2012;1. https://doi.org/10.5005/jpjournals-10025-1013.

12. Randleman JB, Caster AI, Banning CS, Stulting RD. Corneal ectasia after photorefractive keratectomy. J Cataract Refract Surg. 2006;32(8):1395-8.

13. Sorkin N, Kaiserman I, Domniz Y, Sela T, Munzer G, Varssano D. Risk assessment for corneal ectasia following photorefractive keratectomy. J Ophthalmol. 2017;2017:1-10.

14. Chiou AGY, Bovet J, de Courten C. Management of corneal ectasia and cataract following photorefractive keratectomy. J Cataract Refract Surg. 2006;32(4):679-80.

15. Malecaze F, Coullet J, Calvas P, Fournié P, Arné J-L, Brodaty C. Corneal ectasia after photorefractive keratectomy for low myopia. Ophthalmology. 2006;113(5):742-6.

16. Leccisotti A. Corneal ectasia after photorefractive keratectomy. Graefe's Arch Clin Exp Ophthalmol. 2007;245(6):869-75.

17. Navas A, Ariza E, Haber A, Fermón S, Velázquez R, Suárez R. Bilateral keratectasia after photorefractive keratectomy. J Refract Surg. 2007;23(9):941-3.

18. Reznik J, Salz JJ, Klimava A. Development of unilateral corneal ectasia after PRK with ipsilateral preoperative forme fruste keratoconus. J Refract Surg. 2008;24(8):843-7.

19. Hashem AN, Hashem AN. Bilateral corneal ectasia after PRK with bowing posterior corneal float as the only preoperative positive topographic finding-case report. J Ophthalmol Related Sci. 2019;3:1-5.

20. Spadea L. Collagen crosslinking for ectasia following PRK performed in excimer laser-assisted 
keratoplasty for keratoconus. Eur J Ophthalmol. 2012;22(2):274-7.

21. Roszkowska AM, Sommario MS, Urso M, Aragona P. Post photorefractive keratectomy corneal ectasia. Int J Ophthalmol. 2017;10(2):315-7.

22. Parmar D, Claoué C. Keratectasia following excimer laser photorefractive keratectomy. Acta Ophthalmol Scand. 2004;82(1):102-5.

23. Kim H, Choi J-S, Joo C-K. Corneal ectasia after PRK. Cornea. 2006;25(7):845-8.

24. Woodward MA, Randleman JB, Russell B, Lynn MJ, Ward MA, Stulting RD. Visual rehabilitation and outcomes for ectasia after corneal refractive surgery. J Cataract Refract Surg. 2008;34(3):383-8.

25. Stival LRS, Nassaralla BRA, de Figueiredo MNFC, Bicalho F, Nassaralla Junior JJ. Intrastromal corneal ring segment implantation for ectasia after refractive surgery. Arq Bras Oftalmol [Internet]. 2015;78(4):212-5.

26. Vinciguerra P, Torres I, Camesasca FI. Applications of confocal microscopy in refractive surgery. J Refract Surg. 2002;18(3 Suppl):S378-81.

27. Ghanem RC, Ghanem VC, Ghanem EA, Kara-José N. Corneal wavefront-guided photorefractive keratectomy with mitomycin-C for hyperopia after radial keratotomy: two-year follow-up. J Cataract Refract Surg. 2012;38(4):595-606.

28. Dawson DG, Randleman JB, Grossniklaus HE, O'Brien TP, Dubovy SR, Schmack I, et al. Corneal ectasia after excimer laser keratorefractive surgery: histopathology, ultrastructure, and pathophysiology. Ophthalmology. 2008;115(12):2181-2191.e1.

29. Soundarya B, Sachdev G, Ramamurthy S, Dandapani R. Ectasia after keratorefractive surgery: analysis of risk factors and treatment outcomes in the Indian population. Indian J Ophthalmol [Internet]. 2020;68(6):1028. http://www.ijo.in/text.asp?2020/ $68 / 6 / 1028 / 284806$.

30. Nasr Y, Jabroun M, Bustros Y. Corneal ectasia fifteen years post photorefractive keratectomy in one eye and laser in-situ keratomileusis in the fellow eye of a Lebanese patient. J Med Liban. 2018;66(5):284-7.

31. Holland SP, Srivannaboon S, Reinstein DZ. Avoiding serious corneal complications of laser assisted in situ keratomileusis and photorefractive keratectomy. Ophthalmology [Internet]. 2000;107(4): 640-52.

32. Lovisolo CF, Fleming JF. Intracorneal ring segments for iatrogenic keratectasia after laser in situ keratomileusis or photorefractive keratectomy. J Refract Surg. 2002;18(5):535-41.

33. Richoz O, Mavrakanas N, Pajic B, Hafezi F. Corneal collagen cross-linking for ectasia after LASIK and photorefractive keratectomy: long-term results. Ophthalmology [Internet]. 2013;120(7):1354-9.

34. Torquetti L, Ferrara P. Intrastromal corneal ring segment implantation for ectasia after refractive surgery. J Cataract Refract Surg. 2010;36(6):986-90.

35. Mortensen JN. Corneal ectasia after PRK. Int J Keratoconus Ectatic Corneal Dis. 2012;1(1):73-4.

36. Benitez A, Velasco R, Carmona C, Babayan A, Baca O. Incidence and risk factors to develop corneal ectasia after refractive surgery. Invest Ophthalmol Vis Sci. 2008;49:2923.

37. Ayala MJ, Abbouda A, Javaloy J. Ectasia post PRK at delayed onset. In: Difficult and complicated cases in refractive surgery [Internet]. Berlin: Springer; 2015. p. 327-30. https://doi.org/10.1007/978-3-64255238-0_71.

38. Miyata K, Takahashi T, Tomidokoro A, Ono K, Oshika T. Iatrogenic keratectasia after phototherapeutic keratectomy. Br J Ophthalmol. 2001;85: 247-8.

39. Koch DD. From the editor: The riddle of iatrogenic keratectasia [Internet]. J Cataract Refractive Surg. 1999;25(4):53-4.

40. Lin Q, Zheng L, Lin X, Wang Q. Keratectasia after laser-assisted subepithelial keratectomy for myopia: a case report. Medicine (Baltimore). 2018;97(12): e0094.

41. Moshirfar M, Fenzl CR, Meyer JJ, Neuffer MC, Espandar L, Mifflin MD (2011) Simultaneous and Sequential Implantation of Intacs and Verisyse Phakic Intraocular Lens for Refractive Improvement in Keratectasia. Cornea 30(2):158-63. https://doi. org/10.1097/ICO.0b013e3181eeb0dd

42. Akhtar S, Alkatan $\mathrm{H}$, Kirat $\mathrm{O}$, Almubrad $\mathrm{T}$. Ultrastructural and three-dimensional study of post-LASIK ectasia cornea. Microsc Res Tech. 2014;77(1):91-8.

43. Bilgihan K, Özdek ŞC, Sari A, Hasanreisoğlu B. Excimer laser-assisted anterior lamellar keratoplasty for keratoconus, corneal problems after laser in situ keratomileusis, and corneal stromal opacities. J Cataract Refract Surg [Internet]. 2006;32(8): 1264-9.

44. Binder PS. Analysis of ectasia after laser in situ keratomileusis: risk factors. J Cataract Refract Surg. 2007;33(9):1530-8. 
45. Bohac M, Koncarevic M, Pasalic A, et al. Incidence and clinical characteristics of post LASIK ectasia: a review of over 30,000 LASIK cases. Semin Ophthalmol [Internet]. 2018;33(7-8):869-77.

46. Brenner LF, Alió JL, Vega-Estrada A, Baviera J, Beltrán J, Cobo-Soriano R. Indications for intrastromal corneal ring segments in ectasia after laser in situ keratomileusis. J Cataract Refract Surg [Internet]. 2012;38(12):2117-24.

47. Bühren J, Schäffeler T, Kohnen T. Preoperative topographic characteristics of eyes that developed postoperative LASIK keratectasia. J Refract Surg [Internet]. 2013;29(8):540-9.

48. Carrasquillo KG, Rand J, Talamo JH. Intacs for keratoconus and post-LASIK ectasia: mechanical versus femtosecond laser-assisted channel creation. Cornea [Internet]. 2007;26(8):956-62.

49. Chan C, Saad A, Randleman JB, Harissi-Dagher M, Chua D, Qazi M, et al. Analysis of cases and accuracy of 3 risk scoring systems in predicting ectasia after laser in situ keratomileusis. J Cataract Refract Surg [Internet]. 2018;44(8):979-92.

50. Chan C, Hodge C, Sutton G. External analysis of the Randleman Ectasia Risk Factor Score System: a review of 36 cases of post LASIK ectasia. J Clin Exp Ophthalmol. 2010;38:335-40.

51. Choi HJ, Kim MK, Lee JL. Optimization of contact lens fitting in keratectasia patients after laser in situ keratomileusis. J Cataract Refract Surg [Internet]. 2004;30(5):1057-66.

52. Chua D, Htoon HM, Lim L, et al. Eighteen-year prospective audit of LASIK outcomes for myopia in 53731 eyes. Br J Ophthalmol. 2019;103:1228-34.

53. Alio JL, Piero DP, Daxer A. Clinical outcomes after complete ring implantation in corneal ectasia using the femtosecond technology: a pilot study. Ophthalmology [Internet]. 2011;118(7):1282-90.

54. Cooke MD, Koenig SB. Spontaneous resolution of acute corneal hydrops in a patient with post-LASIK ectasia. Cornea. 2015;34(7):835-7.

55. Galperin G, Berra M, Berra A. Keratectasia following laser in situ keratomileusis in a low-risk patient with benign joint hypermobility syndrome. Arq Bras Oftalmol [Internet]. 2014;77(2):119-21.

56. Geggel HS. Delayed onset keratectasia following laser in situ keratomileusis. J Cataract Refract Surg. 1999;25(4):582-6.

57. Greenstein SA, Fry KL, Hersh PS. In vivo biomechanical changes after corneal collagen cross-linking for keratoconus and corneal ectasia: 1-Year analysis of a randomized, controlled, clinical trial. Cornea [Internet]. 2012;31(1):21-5.

58. Hafezi F, Kanellopoulos J, Wiltfang R, Seiler T. Corneal collagen crosslinking with riboflavin and ultraviolet A to treat induced keratectasia after laser in situ keratomileusis. J Cataract Refract Surg. 2007;33(12):2035-40.

59. Harissi-Dagher M, Frimmel SAF, Melki S. High myopia as a risk factor for post-LASIK ectasia: a case report. Clin Surg Ophthalmol [Internet]. 2009;27(8):206-9.

60. Hashemi H, Gholaminejad A, Amanzadeh K, Hashemi M, Khabazkhoob M. Single-segment and double-segment INTACS for post-LASIK ectasia. Acta Med Iran. 2014;52(9):681-6.

61. Hiatt JA, Wachler BSB, Grant C. Reversal of laser in situ keratomileusis-induced ectasia with intraocular pressure reduction. J Cataract Refract Surg. 2005;31(8):1652-5.

62. Hodge C, Lawless M, Sutton G. Keratectasia following LASIK in a patient with uncomplicated PRK in the fellow eye. J Cataract Refract Surg [Internet]. 2011;37(3):603-7.

63. Jabbarvand M, Hashemian M, Hashemian H, Bazvand $\mathrm{F}$, Khodaparast M. Femtosecond laser-assisted MyoRing implantation in postoperative LASIK ectasia. J Refract Surg [Internet]. 2014;30(7):462-6.

64. Alió JL, Soria F, Abbouda A, Peña-García P. Laser in situ keratomileusis for -6.00 to -18.00 diopters of myopia and up to -5.00 diopters of astigmatism: 15-year follow-up. J Cataract Refract Surg. 2015;41(1):33-40.

65. Jabbur NS, Stark WJ, Green WR. Corneal ectasia after laser-assisted in situ keratomileusis. Arch Ophthalmol [Internet]. 2001;119(11):1714-6.

66. Jarade EF, Chelala E, Arej N, El Rami H. Inducing fibrogenesis and new interfibrillary bonds in postlaser in situ keratomileusis keratectasia. J Cataract Refract Surg [Internet]. 2018;44(9):1062-5.

67. Javadi MA, Feizi S. Deep anterior lamellar keratoplasty using the big-bubble technique for keratectasia after laser in situ keratomileusis. J Cataract Refract Surg [Internet]. 2010;36(7):1156-60.

68. Ali Javadi M, Kanavi MR, Mahdavi M, Yaseri M, Rabiei HM, Javadi A, et al. Comparison of keratocyte density between keratoconus, post-laser in situ keratomileusis keratectasia, and uncomplicated post-laser in situ keratomileusis cases. A confocal scan study. Cornea [Internet]. 2009;28(7):774-9. 
69. Javadi MA, Mohammadpour M, Rabei HM. Keratectasia after LASIK but not after PRK in one patient. J Refract Surg. 2006;22(8):817-20.

70. Jiang Y, Li Y, Yang S, Lu TC. Tuck-in Lamellar keratoplasty with an lenticule obtained by small incision lenticule extraction for treatment of PostLASIK Ectasia. Sci Rep [Internet]. 2017;7(1):17806.

71. Alvani A, Hashemi H, Pakravan M, Mahbod M, Seyedian MA, Amanzadeh K, et al. Post-LASIK ectasia versus keratoconus: an in vivo confocal microscopy study. Cornea [Internet]. 2020;39(8): 1006-12.

72. Ambrósio RJ, Dawson DG, Salomão M, Guerra FP, Caiado ALC, Belin MW. Corneal ectasia after LASIK despite low preoperative risk: tomographic and biomechanical findings in the unoperated, stable, fellow eye. J Refract Surg. 2010;26(11):906-11.

73. Amoils SP, Deist MB, Gous P, Amoils PM. Iatrogenic keratectasia after laser in situ keratomileusis for less than -4.0 to -7.0 diopters of myopia. J Cataract Refract Surg [Internet]. 2000;26(7):967-77.

74. Argento C, Cosentino MJ, Tytiun A, Rapetti G, Zarate J. Corneal ectasia after laser in situ keratomileusis. J Cataract Refract Surg. 2001;27(9): 1440-8.

75. Badawi AE. Corneal endothelial changes after accelerated corneal collagen cross-linking in keratoconus and postLASIK ectasia. Clin Ophthalmol [Internet]. 2016;10:1891-8.

76. Bevara A, Vaddavalli PK. Compression sutures to treat acute hydrops in a case of bilateral post-laser in situ keratomileusis ectasia. Cornea [Internet]. 2021;40(5):659-61.

77. Kamburoglu G, Ertan A. Intacs implantation with sequential collagen cross-linking treatment in postoperative LASIK ectasia. J Refract Surg. 2008;24(7):S726-9.

78. Kanellopoulos AJ. Post-LASIK ectasia. Ophthalmology. 2007;114:1230.

79. Kanellopoulos AJ, Binder PS. Management of corneal ectasia after LASIK with combined, same-day, topography-guided partial transepithelial PRK and collagen cross-linking: the Athens protocol. J Refract Surg. 2011;27(5):323-31.

80. Moscovic BK, Campos M. Intrastromal crosslinking in post-LASIK ectasia. Arq Bras Oftalmol [Internet]. 2014;77(3):191-2. https://doi.org/10.5935/00042749.20140049 .

81. Tae HK, Lee D, Hyeon IL. The safety of $250 \mu \mathrm{m}$ residual stromal bed in preventing keratectasia after laser in situ keratomileusis (LASIK). J Korean Med Sci [Internet]. 2007;22(1):142-5.

82. Klein SR, Epstein RJ, Randleman JB, Stulting RD. Corneal ectasia after laser in situ keratomileusis in patients without apparent preoperative risk factors. Cornea [Internet]. 2006;25(4):388-403.

83. Joo CK, Kim TG. Corneal ectasia detected after laser in situ keratomileusis for correction of less than -12 diopters of myopia. J Cataract Refract Surg [Internet]. 2000;26(2):292-5.

84. Kraff CR, Probst LE, Tooma T, Will BR. Post-LASIK ectasia. Cataract Refract Surgery Today Refract Surgery Complications Manage. 2007;71-4.

85. Moshirfar M, Smedley JG, Muthappan V, Jarsted A, Ostler EM. Rate of ectasia and incidence of irregular topography in patients with unidentified preoperative risk factors undergoing femtosecond laser-assisted LASIK. Clin Ophthalmol [Internet]. 2013;8: $35-42$.

86. Randleman JB, Woodward M, Lynn MJ, Stulting RD. Risk assessment for ectasia after corneal refractive surgery. Ophthalmology [Internet]. 2008;115(1): 37-50.

87. Spirn MJ, Dawson DG, Rubinfeld RS, Burris C, Talamo J, Edelhauser HF, et al. Histopathological analysis of post-laser-assisted in situ keratomileusis corneal ectasia with intrastromal corneal ring segments. Arch Ophthalmol. 2005;123(11):1604-7.

88. Randleman JB, Hebson CB, Larson PM. Flap thickness in eyes with ectasia after laser in situ keratomileusis. J Cataract Refract Surg [Internet]. 2012;38(5):752-7.

89. Spadea L, Cantera E, Cortes M, Conocchia NE, Stewart CWM. Corneal ectasia after myopic laser in situ keratomileusis: a long-term study. Clin Ophthalmol [Internet]. 2012;6(1):1801-13.

90. Miraftab M, Fotouhi A, Hashemi H, Jafari F, Shahnazi A, Asgari S. A modified risk assessment scoring system for post laser in situ keratomileusis ectasia in topographically normal patients [Internet]. J Ophthalmic Vis Res. 2014;9:434-8.

91. Zhu W, Han Y, Cui C, Xu W, Wang X, Dou X, et al. Corneal collagen crosslinking combined with phototherapeutic keratectomy and photorefractive keratectomy for corneal ectasia after laser in situ keratomileusis. Ophthalmic Res [Internet]. 2018;59(3):135-41.

92. Lopes BT, Ramos IC, Salomão MQ, Guerra FP, Schallhorn SC, Schallhorn JM, et al. Enhanced tomographic assessment to detect corneal ectasia 
based on artificial intelligence. Am J Ophthalmol [Internet]. 2018;195:223-32.

93. Yildirim A, Cakir H, Kara N, Uslu H, Gurler B, Ozgurhan EB, et al. Corneal collagen crosslinking for ectasia after laser in situ keratomileusis: longterm results. J Cataract Refract Surg [Internet]. 2014;40(10):1591-6.

94. Yildirim A, Uslu H, Kara N, Cakir H, Gurler B, Colak $\mathrm{HN}$, et al. Same-day intrastromal corneal ring segment and collagen cross-linking for ectasia after laser in situ keratomileusis: long-term results. Am J Ophthalmol [Internet]. 2014;157(5):1070-76.

95. Piñero DP, Alió JL, Barraquer RI, Uceda-Montanes A, Murta J. Clinical characterization of corneal ectasia after myopic laser in situ keratomileusis based on anterior corneal aberrations and internal astigmatism. J Cataract Refract Surg [Internet]. 2011;37(7): 1291-9.

96. Magallanes R, Shah S, Zadok D, Chayet AS, Assil KK, Montes $\mathrm{M}$, et al. Stability after laser in situ keratomileusis in moderately and extremely myopic eyes. J Cataract Refract Surg [Internet]. 2001;27(7): 1007-12.

97. Piñero DP, Alio JL, Uceda-Montanes A, El KB, Pascual I. Intracorneal ring segment implantation in corneas with post-laser in situ keratomileusis keratectasia. Ophthalmology [Internet]. 2009;116(9): 1665-74.

98. Pahuja NK, Shetty R, Deshmukh R, Sharma A, Nuijts RMMA, Jhanji $V$, et al. In vivo confocal microscopy and tear cytokine analysis in post-LASIK ectasia [Internet]. Br J Ophthalmol. 2017;101:1604-10.

99. Kymionis GD, Diakonis VF, Kalyvianaki M, Portaliou D, Siganos C, Kozobolis VP, et al. One-year follow-up of corneal confocal microscopy after corneal cross-linking in patients with post laser in situ keratosmileusis ectasia and keratoconus. Am J Ophthalmol [Internet]. 2009;147(5):774-8.

100. Salouti R, Nowroozzadeh MH, Makateb P, Zamani M, Ghoreyshi M, Melles GRJ. Deep anterior lamellar keratoplasty for keratectasia after laser in situ keratomileusis. J Cataract Refract Surg [Internet]. 2014;40(12):2011-8.

101. Kymionis GD, Portaliou DM, Diakonis VF, Karavitaki AE, Panagopoulou SI, Jankov Ii MR, et al. Management of post laser in situ keratomileusis ectasia with simultaneous topography guided photorefractive keratectomy and collagen cross-linking. Open Ophthalmol J. 2011;5:11-3.

102. Padmanabhan P, Rachapalle Reddi S, Sivakumar PD. Topographic, tomographic, and aberrometric characteristics of post-LASIK ectasia. Optom Vis Sci. 2016;93(11):1364-70.

103. Kucumen RB, Yenerel NM, Gorgun E, Oncel M. Penetrating keratoplasty for corneal ectasia after laser in situ keratomileusis. Eur J Ophthalmol. 2008;18(5):695-702.

104. Philipp WE, Speicher L, Göttinger W. Histological and immunohistochemical findings after laser in situ keratomileusis in human corneas. J Cataract Refract Surg [Internet]. 2003;29(4):808-20.

105. Modabber M, Darvish-Zargar M, Breton L, Chung DD, Duong $\mathrm{H}$, Aldave AJ, et al. Crystalline keratopathy in post-LASIK ectasia: a case report. Cornea [Internet]. 2019;38:635-8.

106. Sheludchenko VM, Osipyan GA, Yusef NY, Khraystin K, Alharki L, Dzhalili RA. Bandage lamellar-optical keratoplasty for post-excimer laser keratectasia. Vestn Oftalmol [Internet]. 2019;135(5):171-6.

107. Rao SK, Srinivasan B, Sitalakshmi G, Padmanabhan P. Photorefractive keratectomy versus laser in situ keratomileusis to prevent keratectasia after corneal ablation. J Cataract Refract Surg [Internet]. 2004;30(12):2623-8.

108. Rao SN, Epstein RJ. Early onset ectasia following laser in situ keratomileusus: case report and literature review. J Refract Surg. 2002;18(2):177-84.

109. Siganos CS, Kymionis GD, Astyrakakis N, Pallikaris IG. Management of corneal ectasia after laser in situ keratomileusis with intacs. J Refract Surg [Internet]. 2002;18(1):43-6.

110. Zhou W, Wang H, Zhang X, Tian M, Cui C, Li X, et al. Management of corneal ectasia after lasik with phototherapeutic keratectomy combined with photorefractive keratectomy and collagen crosslinking. J Ophthalmol [Internet]. 2019;2019: 2707826 .

111. Sharif W, Ali ZR, Sharif K. Long term efficacy and stability of corneal collagen cross linking for postLASIK ectasia: An average of $80 \mathrm{mo}$ follow-up. Int J Ophthalmol [Internet]. 2019;12(2):333-7.

112. Qin V, Saad A, Gatinel D. Unilateral post-LASIK ectasia and contralateral spontaneous ectasia. J Refract Surg. 2016;32(2):127-30.

113. Tong JY, Viswanathan D, Hodge C, Sutton G, Chan C, Males JJ. Corneal collagen crosslinking for postlasik ectasia: an Australian study. Asia-Pacific J Ophthalmol [Internet]. 2017;6(3):228-32.

114. Tatar MG, Aylin Kantarci F, Yildirim A, Uslu H, Colak HN, Goker H, et al. Risk factors in post-LASIK 
corneal ectasia. J Ophthalmol [Internet]. 2014;2014: $1-4$.

115. Lam K, Rootman DB, Lichtinger A, Rootman DS. Post-LASIK ectasia treated with intrastromal corneal ring segments and corneal crosslinking. Digit J Ophthalmol [Internet]. 2013;19(1):1-5.

116. Li G, Fan ZJ, Peng XJ. Corneal collagen crosslinking for corneal ectasia of post-LASIK: one-year results. Int J Ophthalmol [Internet]. 2012;5(2):190-5.

117. Kymionis GD, Siganos CS, Kounis G, Astyrakakis N, Kalyvianaki MI, Pallikaris IG. Management of postLASIK corneal ectasia with Intacs inserts: one-year results. Arch Ophthalmol [Internet]. 2003;121(3): 322-6.

118. Kymionis GD, Tsiklis NS, Pallikaris AI, Kounis G, Diakonis VF, Astyrakakis N, et al. Long-term Followup of Intacs for Post-LASIK Corneal Ectasia. Ophthalmology [Internet]. 2006;113(11):1909-17.

119. Maeda N, Nakagawa T, Kosaki R, Koh S, Saika M, Fujikado T, et al. Higher-order aberrations of anterior and posterior corneal surfaces in patients with keratectasia after LASIK. Investig Ophthalmol Vis Sci [Internet]. 2014;55(6):3905-11.

120. Tunc Z, Helvacioglu F, Sencan S. Evaluation of intrastromal corneal ring segments for treatment of post-LASIK ectasia patients with a mechanical implantation technique. Indian J Ophthalmol [Internet]. 2011;59(6):437-43.

121. Ueki R, Maeda N, Fuchihata M, Asai T, Koh S, Fujimoto $\mathrm{H}$, et al. Evaluation of corneal biomechanics in patients with keratectasia following LASIK using dynamic Scheimpflug analyzer. Jpn J Ophthalmol [Internet]. 2018;62(4):443-50.

122. Vajpayee RB, Sinha R, Sharma N, Titiyal JS, Tandon R. Posterior corneal ectasia following LASIK. Klin Oczna [Internet]. 2005;107(1-3):46-8.

123. Marino GK, Torricelli AAM, Giacomin N, Santhiago MR, Espindola R, Netto MV. Accelerated corneal collagen cross-linking for postoperative LASIK Ectasia: two-year outcomes. J Refract Surg. 2015;31(6):380-4.

124. Piccoli PM, Gomes AAC, Piccoli FVR. Corneal ectasia detected 32 months after LASIK for correction of myopia and asymmetric astigmatism. J Cataract Refract Surg. 2003;29(6):1222-5.

125. Rodríguez LA, Villegas AE, Porras D, Benavides MA, Molina J. Treatment of six cases of advanced ectasia after LASIK with 6-mm intacs SK. J Refract Surg [Internet]. 2009;25(12):1116-9.
126. Vinciguerra P, Camesasca FI, Albè E, Trazza S. Corneal collagen cross-linking for ectasia after excimer laser refractive surgery: 1-year results. J Refract Surg. 2010;26(7):486-97.

127. McAllum PJ, Segev F, Herzig S, Rootman DS. Deep anterior lamellar keratoplasty for post-LASIK ectasia. Cornea [Internet]. 2007;26(4):507-11.

128. Kymionis GD, Bouzoukis DI, Portaliou DM, Pallikaris IG. New INTACS SK implantation in patients with post-laser in situ keratomileusis corneal ectasia. Cornea [Internet]. 2010;29(2):214-6.

129. Wallerstein A, Adiguzel E, Gauvin M, MohammadShahi N, Cohen M. Under-flap stromal bed CXL for early post-LASIK ectasia: a novel treatment technique. Clin Ophthalmol [Internet]. 2017;11:1-8.

130. Yang J, Bauer BA, Wahner-Roedler DL, Chon TY, Xiao L. The modified WHO analgesic ladder: is it appropriate for chronic non-cancer pain? J Pain Res. 2020. https://doi.org/10.2147/JPR.S244173.

131. Lu Y, Shi YH, Yang LP, Ge YR, Chen XF, Wu Y, et al. Femtosecond laser-assisted deep anterior lamellar keratoplasty for keratoconus and keratectasia. Int J Ophthalmol [Internet]. 2014;7(4):638-43.

132. Salgado JP, Khoramnia R, Lohmann CP, Winkler Von Mohrenfels C. Corneal collagen crosslinking in post-LASIK keratectasia. Br J Ophthalmol [Internet]. 2011;95(4):493-7.

133. Peris-Martínez C, Bueno-Gimeno I, Alvarez-Arana I, Piñero DP, Gené-Sampedro A. Characterization of the effect of intracorneal ring segment in corneal ectasia after laser refractive surgery. Eur J Ophthalmol [Internet]. 2020;30(1):125-31. https://doi.org/ $10.1177 / 1120672118808968$.

134. Saad A, Gatinel D. Bilateral corneal ectasia after laser in situ keratomileusis in patient with isolated difference in central corneal thickness between eyes. J Cart Refract Surg [Internet]. 2021;36:1033-5.

135. Uceda-Montanes A, Tomás JD, Alió JL. Correction of severe ectasia after LASIK with intracorneal ring segments. J Refract Surg. 2008;24(4):408-11.

136. Lifshitz T, Levy J, Klemperer I, Levinger S. Late bilateral keratectasia after LASIK in a low myopic patient. J Refract Surg. 2005;21(5):494-6.

137. Li M, Wei R, Yang W, Shang J, Fu D, Xia F, et al. Femtosecond laser-assisted allogenic lenticule implantation for corneal ectasia after LASIK: a 3 -year in vivo confocal microscopic investigation. J Refract Surg. 2020;36(11):714-22.

138. McLeod SD, Kisla TA, Caro NC, McMahon TT. Iatrogenic keratoconus: corneal ectasia following 
laser in situ keratomileusis for myopia. Arch Ophthalmol [Internet]. 2000;118(2):282-4.

139. Mian SZ, Agranat JS, Jacobs DS. Prosthetic Replacement of the Ocular Surface Ecosystem (PROSE) treatment for complications after LASIK. Eye Contact Lens [Internet]. 2016;42(6):371-3.

140. Neuffer MC, Panday V, Reilly C. Intrastromal corneal ring segments for post-LASIK ectasia complicated by persistent pain. J Cart Refract Surg. 2010;36:336-9.

141. Ou RJ, Shaw EL, Glasgow BJ. Keratectasia after laser in situ keratomileusis (LASIK): evaluation of the calculated residual stromal bed thickness. Am J Ophthalmol [Internet]. 2002;134(5):771-3.

142. Padmanabhan P, Radhakrishnan A, Natarajan R. Pregnancy-triggered iatrogenic (post-laser in situ keratomileusis) corneal ectasia-a case report. Cornea [Internet]. 2010;29(5):569-72.

143. Said A, Hamade IH, Tabbara KF. Late onset corneal ectasia after LASIK surgery. Saudi J Ophthalmol [Internet]. 2011;25(3):225-30.

144. Tuli SS, Iyer S. Delayed ectasia following LASIK with no risk factors: is a 300-microm stromal bed enough? J Refract Surg. 2007;23(6):620-2.

145. Wang JC, Hufnagel TJ, Buxton DF. Bilateral keratectasia after unilateral laser in situ keratomileusis: a retrospective diagnosis of ectatic corneal disorder. J Cataract Refract Surg. 2003;29(10):2015-8.

146. Rad AS, Jabbarvand M, Saifi N. Progressive keratectasia after laser in situ keratomileusis. J Refract Surg. 2004;20(5 Suppl):S718-22.

147. Reinstein DZ, Srivannaboon S, Archer TJ, Silverman $\mathrm{RH}$, Sutton H, Coleman DJ. Probability model of the inaccuracy of residual stromal thickness prediction to reduce the risk of ectasia after LASIK part II: quantifying population risk. J Refract Surg. 2006;22(9):861-70.

148. Santhiago MR, Smadja D, Gomes BF, Mello GR, Monteiro MLR, Wilson SE, et al. Association between the percent tissue altered and post-laser in situ keratomileusis ectasia in eyes with normal preoperative topography. Am J Ophthalmol. 2014;158(1):87-95.e1.

149. Sharma M, Boxer Wachler BS. Comparison of single-segment and double-segment Intacs for keratoconus and post-LASIK ectasia. Am J Ophthalmol. 2006;141(5):891-5.

150. Mahadevan R, Jagadeesh D, Rajan R, Arumugam AO. Unique hard scleral lens post-LASIK ectasia fitting. Optom Vis Sci [Internet]. 2014;91(4 SUPPL. 1):S30-1.

151. Zhao W, Shen Y, Jian W, Shang J, Jhanji V, Aruma A, et al. Comparison of corneal biomechanical properties between post-LASIK ectasia and primary keratoconus. J Ophthalmol [Internet]. 2020;2020: 5291485.

152. Mandathara PS, Kalaiselvan P, Rathi VM, Murthy SI, Taneja M, Sangwan VS. Contact lens fitting after corneal collagen cross-linking. Oman J Ophthalmol [Internet]. 2019;12(3):177-80.

153. Arnal E, Peris-Martínez C, Menezo JL, Johnsen-Soriano S, Romero FJ. Oxidative stress in keratoconus? Investig Ophthalmol Vis Sci [Internet]. 2011;52(12): 8592-7.

154. Lafond G, Bazin R, Lajoie C. Bilateral severe keratoconus after laser in situ keratomileusis in a patient with forme fruste keratoconus. J Cataract Refract Surg [Internet]. 2001;27(7):1115-8.

155. Chiang RK, Park AJ, Rapuano CJ, Cohen EJ. Bilateral keratoconus after LASIK in a keratoconus patient. Eye Contact Lens [Internet]. 2003;29(2):90-2.

156. Kumar M, Shetty R, Lalgudi VG, Khamar P, Vincent SJ, Atchison DA. The effect of scleral lenses on vision, refraction and aberrations in post-LASIK ectasia, keratoconus and pellucid marginal degeneration. Ophthalmic Physiol Opt J Br Coll Ophthalmic Opt. 2021;41:664-72.

157. Brooks NO, Greenstein S, Fry K, Hersh PS. Patient subjective visual function after corneal collagen crosslinking for keratoconus and corneal ectasia. J Cataract Refract Surg. 2012;38(4):615-9.

158. Poli M, Cornut P-L, Balmitgere T, Aptel F, Janin H, Burillon C. Prospective study of corneal collagen cross-linking efficacy and tolerance in the treatment of keratoconus and corneal ectasia: 3-year results. Cornea. 2013;32(5):583-90.

159. Ondes Yilmaz F, Kepez Yildiz B, Demirok A. Detection of subclinical corneal ectasia after laser in situ keratomileusis: Corvis ST. Beyoglu Eye J [Internet]. 2021;6(2):0. https://doi.org/10.14744/bej.2021. 32559.

160. Moshirfar M, Mirzaian G, Marx D. Ectasia after LASIK. Cataract and Refractive Surgery Today. 2005. https://crstoday.com/articles/2005-jul/crst0705_11$\mathrm{php} /$.

161. El-Naggar MT. Bilateral ectasia after femtosecond laser-assisted small-incision lenticule extraction. J Cataract Refract Surg. 2015;41(4):884-8. 
162. Gavrilov JC, Atia R, Borderie V, Laroche L, Bouheraoua N. Unilateral corneal ectasia after small-incision lenticule extraction in a 43-year-old patient. J Cataract Refract Surg. 2018;44(3):403-6.

163. Ge Q, Cui C, Wang J, Mu G. Combined transepithelial phototherapeutic keratectomy and corneal collagen cross-linking for corneal ectasia after smallincision lenticule extraction-preoperative and 3-year postoperative results: a case report. BMC Ophthalmol. 2018;18(1):175.

164. Khamar P, Dalal R, Chandapura R, Francis M, Shetty $\mathrm{R}$, Nelson EJR, et al. Corneal tomographic features of postrefractive surgery ectasia. J Biophotonics. 2019;12(2):e201800253.

165. Mattila JS, Holopainen JM. Bilateral ectasia after femtosecond laser-assisted small incision lenticule extraction (SMILE). J Refract Surg. 2016;32(7): 497-500.

166. Pazo EE, McNeely RN, Arba-Mosquera S, Palme C, Moore JE. Unilateral ectasia after small-incision lenticule extraction. J Cataract Refract Surg. 2019;45(2):236-41.

167. Sachdev G, Sachdev MS, Sachdev R, Gupta H. Unilateral corneal ectasia following small-incision lenticule extraction. J Cataract Refract Surg. 2015;41(9):2014-8.

168. Shetty R, Kumar NR, Khamar P, Francis M, Sethu S, Randleman JB, et al. Bilaterally asymmetric corneal ectasia following SMILE with asymmetrically reduced stromal molecular markers. J Refract Surg. 2019;35(1):6-14.

169. Voulgari N, Mikropoulos D, Kontadakis GA, Safi A, Tabibian D, Kymionis GD. Corneal scarring and hyperopic shift after corneal cross-linking for corneal ectasia after SMILE. J Refract Surg. 2018;34(11): 779-82.

170. Wang Y, Cui C, Li Z, Tao X, Zhang C, Zhang X, et al. Corneal ectasia 6.5 months after small-incision lenticule extraction. J Cataract Refract Surg. 2015;41(5):1100-6.

171. CDC. Principles of Epidemiology | Lesson 3-Section 2 [Internet]. https://www.cdc.gov/csels/dsepd/ ss1978/lesson3/section2.html.

172. Ota R, Fujiki K, Nakayasu K. Estimation of patient visit rate and incidence of keratoconus in the 23 wards of Tokyo. Nihon Ganka Gakkai Zasshi. 2002;106(6):365-72.

173. Xia LK, Yu J, Chai GR, Wang D, Li Y. Comparison of the femtosecond Laser and mechanical microkeratome for flap cutting in LASIK. Int J Ophthalmol [Internet]. 2015;8(4):784-90.
174. Zhang M, Zhang F, Li Y, Song Y, Wang Z. Early diagnosis of keratoconus in chinese myopic eyes by combining corvis ST with pentacam. Curr Eye Res. 2020;45(2):118-23.

175. Yang K, Xu L, Fan Q, et al. Evaluation of new Corvis ST parameters in normal, Post-LASIK, Post-LASIK keratectasia and keratoconus eyes. Sci Rep. 2020. https://doi.org/10.1038/s41598-020-62825-y.

176. Schmack I, Dawson DG, McCarey BE, Waring GO, Grossniklaus HE, Edelhauser HF. Cohesive tensile strength of human LASIK wounds with histologic, ultrastructural, and clinical correlations. J Refract Surg. 2005;21(5):433-45.

177. Shah R. History and results; indications and contraindications of SMILE, compared with LASIK [Internet]. Asia-Pacific J Ophthalmol. 2019;8:371-6.

178. Reinstein DZ, Archer TJ, Gobbe M. Small incision lenticule extraction (SMILE) history, fundamentals of a new refractive surgery technique and clinical outcomes. Eye Vis [Internet]. 2014;1(1):1-12.

179. Ambrósio R. Violet june: the global keratoconus awareness campaign [Internet]. Ophthalmol Therapy. 2020;9:685-8.

180. Pearson AR, Soneji B, Sarvananthan N, SanfordSmith JH. Does ethnic origin influence the incidence or severity of keratoconus? Eye [Internet]. 2000;14(4):625-8.

181. Georgiou T, Funnell CL, Cassels-Brown A, O'Conor $\mathrm{R}$. Influence of ethnic origin on the incidence of keratoconus and associated atopic disease in Asians and white patients. Eye (Lond)[Internet]. 2004;18(4):379-83.

182. Cozma I, Atherley C, James NJ, Georgiou T, Funnell $\mathrm{CL}$, Cassels-Brown A, et al. Influence of ethnic origin on the incidence of keratoconus and associated atopic disease in Asian and white patients (multiple letters) [7] [Internet]. Eye. 2005;19:924-6.

183. Bak-Nielsen S, Ramlau-Hansen $\mathrm{CH}$, Ivarsen $\mathrm{A}$, Plana-Ripoll O, Hjortdal J. Incidence and prevalence of keratoconus in Denmark-an update. Acta Ophthalmol [Internet]. 2019;97(8):752-5.

184. Rabinowitz YS. Keratoconus. Surv Ophthalmol. 1998;42(4):297-319.

185. Ferdi AC, Nguyen V, Gore DM, Allan BD, Rozema JJ, Watson SL. Keratoconus natural progression: a systematic review and meta-analysis of 11529 eyes. Ophthalmology. 2019;126(7):935-45.

186. Zeiss. SMILE: A brief guide - Minimally invasive laser eye surgery for vision correction. [Internet]. https://www.zeiss.com/vision-care/int/better- 
vision/health-prevention/smile-laser-eye-surgery. html\#1.

187. Lundström M, Manning S, Barry P, Stenevi U, Henry Y, Rosen P. The European registry of quality outcomes for cataract and refractive surgery (EUREQUO): a database study of trends in volumes, surgical techniques and outcomes of refractive surgery. Eye Vis (Lond) [Internet]. 2015;2(1):8.

188. Kennedy RH, Bourne WM, Dyer JA. A 48-year clinical and epidemiologic study of keratoconus. Am J Ophthalmol. 1986;101(3):267-73.

189. Ihalainen A. Clinical and epidemiological features of keratoconus genetic and external factors in the pathogenesis of the disease. Acta Ophthalmol Suppl (Oxf ). 1986;178:1-64.

190. Gorskova EN, Sevost'ianov EN. Epidemiology of keratoconus in the Urals. Vestn Oftalmol. 1998;114(4):38-40.

191. Grünauer-Kloevekorn C, Duncker GI. Keratoconus: epidemiology, risk factors and diagnosis. Klin Monbl Augenheilkd. 2006;223(6):493-502.

192. Godefrooij DA, de Wit GA, Uiterwaal CS, Imhof SM, Wisse RPL. Age-specific Incidence and prevalence of keratoconus: a Nationwide Registration Study. Am J Ophthalmol. 2017;1(175):169-72.

193. Assiri AA, Yousuf BI, Quantock AJ, Murphy PJ. Incidence and severity of keratoconus in Asir province. Saudi Arabia Br J Ophthalmol. 2005;89(11): 1403-6.
194. Jonas JB, Nangia V, Matin A, Kulkarni M, Bhojwani $\mathrm{K}$. Prevalence and associations of keratoconus in rural Maharashtra in Central India: the Central India Eye and Medical Study. Am J Ophthalmol [Internet]. 2009;148(5):760-5.

195. Hwang S, Lim DH, Chung T-Y. Prevalence and incidence of keratoconus in South Korea: a nationwide population-based study. Am J Ophthalmol. 2018;192:56-64.

196. Millodot M, Shneor E, Albou S, Atlani E, GordonShaag A. Prevalence and associated factors of keratoconus in Jerusalem: a cross-sectional study. Ophthalmic Epidemiol. 2011;18(2):91-7.

197. Ziaei H, Jafarinasab MR, Javadi MA, Karimian F, Poorsalman H, Mahdavi M, et al. Epidemiology of keratoconus in an Iranian population. Cornea. 2012;31(9):1044-7.

198. Althomali TA, Al-Qurashi IM, Al-Thagafi SM, Mohammed A, Almalki M. Prevalence of keratoconus among patients seeking laser vision correction in Taif area of Saudi Arabia. Saudi J Ophthalmol Off J Saudi Ophthalmol Soc. 2018;32(2):114-8.

199. Akowuah PK, Kobia-Acquah E, Donkor R, AdjeiAnang J, Ankamah-Lomotey S. Keratoconus in Africa: a systematic review and meta-analysis. Ophthalmic Physiol Opt J Br Coll Ophthalmic Opt. 2021;41:736-41. 